\title{
Non-methane hydrocarbon (NMHC) fingerprints of major urban and agricultural emission sources for use in source apportionment studies
}

\author{
Ashish Kumar ${ }^{1}$ 요, Vinayak Sinha $^{1}$, Muhammed Shabin ${ }^{1}$, Haseeb Hakkim ${ }^{1}$, Bernard Bonsang ${ }^{2}$, and Valerie Gros ${ }^{2}$ \\ ${ }^{1}$ Department of Earth and Environmental Sciences, Indian Institute of Science Education and Research Mohali, \\ Sector 81, S. A. S. Nagar, Manauli PO, Punjab, 140306, India \\ ${ }^{2}$ Laboratoire des Sciences du Climat et de 1'Environnement (LSCE), CNRS/CEA/UVSQ, IPSL, Université Paris-Saclay, \\ F91191 Gif-sur-Yvette, France \\ Invited contribution by Ashish Kumar, recipient of the EGU Atmospheric Sciences Outstanding Student Poster \\ and PICO Award 2019.
}

Correspondence: Vinayak Sinha (vsinha@iisermohali.ac.in)

Received: 19 December 2019 - Discussion started: 20 January 2020

Revised: 5 September 2020 - Accepted: 17 September 2020 - Published: 26 October 2020

\begin{abstract}
In complex atmospheric emission environments such as urban agglomerates, multiple sources control the ambient chemical composition driving air quality and regional climate. In contrast to pristine sites, where reliance on single or a few chemical tracers is often adequate for resolving pollution plumes and source influences, the comprehensive chemical fingerprinting of sources using nonmethane hydrocarbons (NMHCs) and the identification of suitable tracer molecules and emission ratios becomes necessary. Here, we characterise and present chemical fingerprints of some major urban and agricultural emission sources active in South Asia, such as paddy stubble burning, garbage burning, idling vehicular exhaust and evaporative fuel emissions. A total of 121 whole air samples were actively collected from the different emission sources in passivated air sampling steel canisters and then analysed for 49 NMHCs (22 alkanes, 16 aromatics, 10 alkenes and one alkyne) using thermal desorption gas chromatography flame ionisation detection. Several new insights were obtained. Propane was found to be present in paddy stubble fire emissions $(8 \%)$, and therefore, for an environment impacted by crop residue fires, the use of propane as a fugitive liquefied petroleum gas (LPG) emission tracer must be done with caution. Propene was found to be $\sim 1.6$ times greater (by weight) than ethene in smouldering paddy fires. Compositional differences were observed between evaporative emissions of domestic LPG
\end{abstract}

and commercial LPG, which are used in South Asia. While the domestic LPG vapours had more propane $(40 \pm 6 \%)$ than $n$-butane $(19 \pm 2 \%)$, the converse was true for commercial LPG vapours ( $7 \pm 6 \%$ and $37 \pm 4 \%$, respectively). Isoprene was identified as a new tracer for distinguishing paddy stubble and garbage burning in the absence of isoprene emissions at night from biogenic sources. Analyses of source-specific inter-NMHC molar ratios revealed that toluene/benzene ratios can be used to distinguish among paddy stubble fire emissions in the flaming $(0.38 \pm 0.11)$ and smouldering stages $(1.40 \pm 0.10)$, garbage burning flaming $(0.26 \pm 0.07)$ and smouldering emissions $(0.59 \pm 0.16)$, and traffic emissions $(3.54 \pm 0.21)$, whereas $i$-pentane $/ n$ pentane can be used to distinguish biomass burning emissions (0.06-1.46) from the petrol-dominated traffic and fossil fuel emissions (2.83-4.13). $i$-butane / $n$-butane ratios were similar (0.20-0.30) for many sources and could be used as a tracer for photochemical ageing. In agreement with previous studies, $i$-pentane, propane and acetylene were identified as suitable chemical tracers for petrol vehicular and evaporative emissions, LPG evaporative and vehicular emissions and flaming-stage biomass fires, respectively. The secondary pollutant formation potential and human health impact of the sources was also assessed in terms of their hydroxyl radical $(\mathrm{OH})$ reactivity $\left(\mathrm{s}^{-1}\right)$, ozone formation potential (OFP; $\mathrm{gO}_{3} / \mathrm{gNMHC}$ ) and fractional benzene, toluene, 
ethylbenzene and xylenes (BTEX) content. Petrol vehicular emissions, paddy stubble fires and garbage fires were found to have a higher pollution potential (at $\geq 95 \%$ confidence interval) relative to the other sources studied in this work. Thus, many results of this study provide a new foundational framework for quantitative source apportionment studies in complex emission environments.

\section{Introduction}

Non-methane hydrocarbons (NMHCs) are an important class of volatile organic compounds (VOCs) that drive atmospheric chemistry and contribute to the formation of tropospheric ozone and secondary organic aerosols (SOAs; Poisson et al., 2000; Hallquist et al., 2009; Derwent et al., 2010; Ortega et al., 2016). Ground level ozone affects ambient air quality, human health and climate, thus making it a primary target in air quality regulations (EPA, 1990). Furthermore, by reacting with the hydroxyl radical $(\mathrm{OH})$, they can also affect the oxidative capacity of the atmosphere (Atkinson, 2000). NMHCs have a wide variety of anthropogenic, pyrogenic and biogenic sources. In urban areas, anthropogenic sources, such as vehicular emissions, industries and fugitive solvent evaporation, dominate the emissions (Barletta et al., 2005; Baker et al., 2008; Kansal, 2009; Jaimes-Palomera et al., 2016). However, in an agrarian and developing economy like India and other parts of South Asia, other major anthropogenic activities like crop residue burning and garbage burning have emerged as poorly regulated emission sources. Every year the northwest Indo-Gangetic Plain (NW-IGP) experiences episodes of large-scale open burning of paddy stubble in the post-harvest months of October and November, where $>12685 \mathrm{~km}^{2}$ of area of Punjab alone is estimated to be burnt in the open farm fields (Badarinath et al., 2006). This results in emission of a large number of gaseous and particulate pollutants into the air and causes severe deterioration in regional air quality (Sarkar et al., 2013; Chandra and Sinha, 2016; Kumar et al., 2016, 2018; Garg et al., 2016; Sharma et al., 2019).

Previous studies have characterised the emissions of selected VOCs, greenhouse gases and primary air pollutants, like benzenoids, carbon monoxide, nitrogen oxides and black carbon (Venkataraman et al., 2006; Sahai et al., 2007), from paddy stubble burning over NW-IGP. However, there is still a considerable deficit in knowledge concerning the speciated non-methane hydrocarbons, which are co-emitted in the smoke (Andreae, 2019; Sinha et al., 2019). The NMHC emissions from different sources, when expressed as emission source profiles (Watson et al., 2001; Hong-li et al., 2017), provide detailed insights for quantitative source apportionment in source receptor models. Moreover, they are helpful for assessing human health risks due to exposure to toxic and hazardous compounds and secondary pollutant forma- tion tendencies and, therefore, assist in prioritisation of pollution control strategies and policies.

The ratio of two NMHCs with different chemical lifetimes can also be used to constrain the photochemical age of air masses and atmospheric transport times (Parrish et al., 1992; McKeen and Liu, 1993). Several source profiles have been compiled for different emission sources in North America (Dallmann et al., 2012; Gentner et al., 2012), Europe (Passant, 2002; Niedojadlo et al., 2007), East Asia (Na et al., 2004; Liu et al., 2008; Zhang et al., 2013; Zheng et al., 2013; Mo et al., 2016; Hong-li et al., 2017) and other areas (Doskey et al., 1999); however, there is still a considerable gap in the data of speciated NMHCs from active emission sources in South Asia. Using the emission source profiles from different regions of the world for modelling and emission inventories can result in large uncertainties as the emissions can change from country to country, depending upon the quality and composition of fuels, combustion practices and vehicular fleet. Therefore, it is essential to have a comprehensive database of regional and local source profiles which can be used to yield more accurate data for the calculation of emissions and source apportionment tools, such as positive matrix factorisation.

In this study, we report the NMHC fingerprinting of paddy stubble burning emissions, garbage burning emissions, fuel evaporative emissions and idling exhaust emissions of vehicles powered by liquefied petroleum gas (LPG), compressed natural gas (CNG), diesel and petrol using 49 speciated NMHCs (22 alkanes, 16 aromatics, 10 alkenes and one alkyne). These compounds were measured using thermal desorption gas chromatography flame ionisation detection (TD-GC-FID). Based on the measured source profiles, chemical tracers were identified to distinguish the varied emission sources and also for use in positive matrix factorisation (PMF) source apportionment models. Furthermore, we assessed the secondary pollutant formation potential and health risks of the sources in terms of their $\mathrm{OH}$ reactivity $\left(\mathrm{s}^{-1}\right)$, ozone formation potential (OFP; $\mathrm{gO}_{3} / \mathrm{gNMHC}$ ) and the fractional sum of benzene, toluene, ethylbenzene and xylenes (BTEX) content.

\section{Materials and methods}

\subsection{Whole air sampling from specific sources in passivated steel canisters}

Table 1 summarises the details of the whole air sample collection experiments for emissions from paddy stubble burning, garbage burning, busy traffic junctions, idling vehicular exhaust emissions and fuel evaporation. The paddy stubble burning samples (three flaming and three smouldering) were collected at an agricultural field in Kurari, Mohali $\left(30.605^{\circ} \mathrm{N}, 76.744^{\circ} \mathrm{E}\right)$, on 4 November 2017 between 16:30 and 18:30 local time (LT). The garbage burning samples (five 
Table 1. Number of samples investigated per source for the measurements of non-methane hydrocarbons (NMHCs) source profiles. Note: liquefied petroleum gas - LPG; compressed natural gas - CNG; light-duty vehicle - LDV; heavy-duty vehicle - HDV.

\begin{tabular}{|c|c|c|}
\hline Sources & Description & No. of samples \\
\hline Paddy stubble burning (flaming stage) & $\begin{array}{l}\text { Agricultural field in Kurari, Mohali }\left(30.605^{\circ} \mathrm{N}, 76.744^{\circ} \mathrm{E}\right) \text { on } \\
4 \text { November } 2017\end{array}$ & 3 \\
\hline Paddy stubble burning (smouldering stage) & $\begin{array}{l}\text { Agricultural field in Kurari, Mohali }\left(30.605^{\circ} \mathrm{N}, 76.744^{\circ} \mathrm{E}\right) \text { on } \\
4 \text { November } 2017\end{array}$ & 3 \\
\hline Garbage burning (flaming stage) & $\begin{array}{l}\text { Waste sorting and disposing stations in Mohali and surrounding villages } \\
\left(30.642-30.699^{\circ} \mathrm{N}, 76.713-76.729^{\circ} \mathrm{E}\right) \text { in February } 2017\end{array}$ & 5 \\
\hline Garbage burning (smouldering stage) & $\begin{array}{l}\text { Waste sorting and disposing stations in Mohali and surrounding villages } \\
\left(30.642-30.699^{\circ} \mathrm{N}, 76.713-76.729^{\circ} \mathrm{E}\right) \text { in February } 2017\end{array}$ & 5 \\
\hline Traffic & $\begin{array}{l}\text { Busy traffic junctions in Chandigarh and Mohali }\left(30.691^{\circ} \mathrm{N}, 76.698^{\circ} \mathrm{E} \text {, }\right. \\
\left.30.678^{\circ} \mathrm{N}, 76.721^{\circ} \mathrm{E} \text { and } 30.717^{\circ} \mathrm{N}, 76.812^{\circ} \mathrm{E}\right) \text { in on } 3,8 \text { and } 15 \text { March } \\
2017 \text { between } 11: 00 \text { and } 17: 00 \text { local time }\end{array}$ & 3 \\
\hline Petrol vehicular exhaust & $\begin{array}{l}\text { Petrol LDV and two wheelers in idling stage in Chandigarh and Mohali } \\
\left(30.660-30.750^{\circ} \mathrm{N}, 76.700-76.840^{\circ} \mathrm{E}\right) \text { between } \\
\text { March } 2017 \text { and October } 2018\end{array}$ & 23 \\
\hline Diesel vehicular exhaust & $\begin{array}{l}\text { Diesel LDV four wheelers and three wheelers and HDV in } \\
\text { idling stage in Chandigarh and Mohali }\left(30.660-30.750^{\circ} \mathrm{N} \text {, }\right. \\
76.700-76.840^{\circ} \text { E) between March } 2017 \text { and October } 2018\end{array}$ & 33 \\
\hline LPG vehicular exhaust & $\begin{array}{l}\text { LPG three wheelers in idling stage in Chandigarh and Mohali } \\
\left(30.660-30.750^{\circ} \mathrm{N}, 76.700-76.840^{\circ} \mathrm{E}\right) \text { between } \\
\text { March } 2017 \text { and October } 2018\end{array}$ & 9 \\
\hline CNG vehicular exhaust & $\begin{array}{l}\text { CNG three wheelers and LDV four wheelers in idling stage in Chandigarh } \\
\text { and Mohali }\left(30.660-30.750^{\circ} \mathrm{N}, 76.700-76.840^{\circ} \mathrm{E}\right) \text { between } \\
\text { March } 2017 \text { and October } 2018\end{array}$ & 7 \\
\hline LPG evaporative emissions & $\begin{array}{l}\text { LPG vapours collected directly from domestic (5) and commercial LPG } \\
\text { cylinders (5) in Mohali, Chandigarh and Panchkula on 13-14 August } 2020\end{array}$ & 10 \\
\hline Petrol evaporative emissions & $\begin{array}{l}\text { Petrol vapours collected directly from the headspace of the fuel tank of the } \\
\text { petrol vehicles between } 13 \text { and } 14 \text { August } 2020 \text { at IISER Mohali campus } \\
\left(30.665^{\circ} \mathrm{N}, 76.730^{\circ} \mathrm{E}\right)\end{array}$ & 10 \\
\hline Diesel evaporative emissions & $\begin{array}{l}\text { Diesel vapours collected directly from the headspace of the fuel tank of the } \\
\text { diesel vehicles between } 13 \text { and } 14 \text { August } 2020 \text { at IISER Mohali campus } \\
\left(30.665^{\circ} \mathrm{N}, 76.730^{\circ} \mathrm{E}\right)\end{array}$ & 10 \\
\hline
\end{tabular}

flaming and five smouldering) were collected at waste sorting and disposing stations in Mohali and surrounding villages $\left(30.642-30.699^{\circ} \mathrm{N}, 76.713-76.729^{\circ} \mathrm{E}\right)$ between 7 and 17 February 2017. Figure S1 shows the flaming and smouldering fires, which were distinguished by a visual inspection of the presence of flame and white smoke as per previous studies (Chandra et al., 2017; Kumar et al., 2018). The fire in the flaming stage showed a clear flame with little smoke, while in the smouldering stage there was white smoke and no flame. The traffic samples were collected from three busy traffic junctions in Chandigarh and Mohali (Sohana Gurudwara Chowk, Mohali, $30.691^{\circ} \mathrm{N}, 76.698^{\circ} \mathrm{E}$; Sector 79 and 80, Chowk, Mohali, $30.678^{\circ} \mathrm{N}, 76.721^{\circ} \mathrm{E}$; and Transport Chowk, Chandigarh, $30.717^{\circ} \mathrm{N}, 76.812^{\circ} \mathrm{E}$ ) from 3 to
15 March 2017. Although the vehicular emissions are known to be dependent upon several factors, their idling operation results in quite high emissions and fuel residues in the exhaust fumes (Yamada et al., 2011; Shancita et al., 2014). This is because, in idling operations, the engine does not work at its peak operating temperature and efficiency (Brodrick et al., 2002), resulting in incomplete fuel combustion (Rahman et al., 2013). In this study, prior to vehicular exhaust sampling, the engine was left running for about $5 \mathrm{~min}$ until it warmed up to normal working temperature $\left(70-90^{\circ} \mathrm{C}\right)$, and then the air was sampled directly from the mouth of the exhaust tailpipe, with the car in a stationary position and the engine running at idle speed. The idling vehicular exhaust samples were collected from 23 petrol vehicles (14 two wheelers and nine 
light-duty four wheelers), 33 diesel vehicles (six three wheelers, 12 light-duty four wheelers and 15 heavy-duty wheelers), nine LPG vehicles (three wheelers) and seven CNG vehicles (six three wheelers and one light-duty four wheeler) from March 2017 to October 2018 in Chandigarh and Mohali $\left(30.660-30.750^{\circ} \mathrm{N}, 76.700-76.840^{\circ} \mathrm{E}\right)$. For a better representation in the results, the most common vehicle models on Indian roads were selected for this study based upon personal field observations and motor vehicle data provided by Ministry of Road Transport and Highways (MoRTH, 2017). The fuel evaporative emissions samples (10 each from the headspace of LPG, petrol and diesel) were collected in Mohali, Chandigarh and Panchkula on 13-14 August 2020. In India, the most commonly used LPG is of two types, namely domestic LPG for household cooking and commercial LPG for various commercial and industrial activities like hotels, restaurants, metallurgical applications, textiles, automotive, etc. Out of the total 10 samples of LPG evaporative emissions, five samples each were of domestic and commercial LPG. For a better representation, the samples of evaporative emissions were also collected from the most common brands of petrol, diesel and LPG fuels sold all over India and in Nepal, Bangladesh and Sri Lanka (namely Indian Oil, Hindustan Petroleum, Bharat Petroleum, Bharat Gas and Indane Gas). In addition, prior to the lighting of fires or turning on the engines, ambient air samples were also collected from the aforementioned sites to correct for ambient background concentrations.

The whole air was actively sampled in commercially available $6 \mathrm{~L}$ passivated SilcoCan air sampling steel canisters (Restek) and then analysed, using a thermal desorption gas chromatograph equipped with a flame ionisation detector (TD-GC-FID), within $1 \mathrm{~d}$ of the sample collection as per the collection procedure described in previous works (Chandra et al., 2017; Vettikkat et al., 2020). Stability tests of the compounds in the canisters were also conducted, which showed that all the measured compounds reported in this work, including alkenes and alkyne, remained stable for up to $3 \mathrm{~d}$. The air was actively sampled into the canisters using a Teflon VOC pump (model N86 KT.45.18; KNF) operating at a flow rate of $\sim 5500 \mathrm{~mL} / \mathrm{min}$ and pressurised up to $30 \mathrm{psi}$. The steel canisters were protected from dust and air particles using a Teflon membrane filter (pore size $-0.45 \mu \mathrm{m}$ ) in the sample inlet line. Prior to each sampling the canisters were cleaned and preconditioned as per EPA Method TO-15, using a TOClean canister cleaner (Wasson-ECE Instrumentation) and humidified nitrogen.

\subsection{NMHC measurements by thermal desorption - gas chromatography-flame ionisation detection (TD-GC-FID)}

NMHCs in the sample air were measured using a gas chromatograph equipped with two flame ionisation detectors (GC-FID 7890B; Agilent Technologies). Sampling and pre- concentration was performed using a thermal desorption (CIA Advantage-HL and Unity 2; Markes International) unit coupled to the GC-FID system. Helium $(99.999 \%$ pure; Sigma Gases and Services) was used as the carrier gas. Hydrogen (99.9995 \%; Precision Hydrogen $100 \mathrm{H}_{2}$ Generator; Peak Scientific), synthetic air (99.999\%; Sigma Gases and Services) and nitrogen (99.9995\%; Precision Nitrogen trace $250 \mathrm{~N}_{2}$ Generator; Peak Scientific) were used as the FID gases (Table S1). Synthetic air (99.9995\%; Precision Zero Air 1.5 gas generator; Peak Scientific) was also used as the purge gas for the Markes thermal desorption unit.

Figure S2 shows the schematic representation of the TDGC-FID instrument during a typical sample injection and chromatographic run. In the first stage, sample air was passed through a Nafion dryer (integrated into the CIA Advantage) to remove water (Badol et al., 2004; Gros et al., 2011). It was then preconcentrated at $-30^{\circ} \mathrm{C}$ (maintained by a Peltier cooling system) at $20 \mathrm{~mL} / \mathrm{min}$ on an ozone precursor trap (U-T17O3P-2S; Markes International). The trap was a quartz tube ( $2 \mathrm{~mm}$ internal diameter; $60 \mathrm{~mm}$ long) containing Tenax TA, Carboxen 1003 and Carbosieve SIII as adsorbents. The preconcentrated trap was thermally desorbed by heating the trap rapidly to $325^{\circ} \mathrm{C}$, and held at this temperature for $20 \mathrm{~min}$, so that all the preconcentrated NMHCs were thermally desorbed. Thermally desorbed NMHCs were then transferred via a heated inlet $\left(130^{\circ} \mathrm{C}\right)$ line onto the $\mathrm{GC}$ instrument consisting of two capillary columns (dimethyl polysiloxane, DB-1; $60 \mathrm{~m} \times 0.25 \mathrm{~mm}, 1.00 \mu \mathrm{m}$ film thickness; Alumina PLOT, $\mathrm{Al}_{2} \mathrm{O}_{3}$ deactivated with $\mathrm{Na}_{2} \mathrm{SO}_{4}$ and $50 \mathrm{~m} \times 0.32 \mathrm{~mm}, 8 \mu \mathrm{m}$ film thickness; Agilent Technologies). Table S1 lists the settings at which the flame ionisation detectors (FIDs) were operated and the oven temperature was ramped. Initially a temperature of $30^{\circ} \mathrm{C}$ was maintained for $12 \mathrm{~min}$, and thereafter it was increased at two subsequent rates of $5^{\circ} \mathrm{C} / \mathrm{min}$ (up to $170^{\circ} \mathrm{C}$ ) and $15^{\circ} \mathrm{C} / \mathrm{min}$ (up to $200^{\circ} \mathrm{C}$ ). The two columns were connected via a Dean's switch, which was turned on after $17 \mathrm{~min}$ of the chromatographic run. In these initial $17 \mathrm{~min}$, the two columns were connected to each other in a series, and the eluents from the first column (DB-1) were directed onto the second column (Alumina PLOT). After $17 \mathrm{~min}$, the series connection between both the columns was broken by turning on the Dean's switch, and the eluents from both columns were directed onto their respective FIDs. $\mathrm{C}_{6}$ and higher NMHCs were resolved on DB-1 column and detected on FID 1, while $\mathrm{C}_{2}-\mathrm{C}_{5}$ NMHCs were resolved on Alumina PLOT column and detected on FID 2. Thus, in a single run, $\mathrm{C}_{2}-\mathrm{C}_{10}$ compounds were measured simultaneously in two chromatograms.

Prior to the sampling, the instrument was calibrated by dynamic dilution with zero air at different mixing ratios (in the range of 2-200 parts per billion - ppb) using a standard gas calibration unit (GCU-s, v2.1; Ionimed, Ionicon Analytik GmbH). A NIST calibrated flow meter (Bios DryCal Definer 220) was used to measure the flows of both the standard gas and zero air mass flow controllers before and af- 
ter the calibration experiments. Figure S3 shows the sensitivity and linearity of NMHCs obtained from the calibration experiments performed over a dynamic range of 2$200 \mathrm{ppb}$ over two sets of calibrations, namely regular calibration of $2-20 \mathrm{ppb}$ and a high mixing ratio calibration of $10-200 \mathrm{ppb}$. This covers a range of 2 orders of magnitude over which the instrument exhibited an excellent linearity $\left(r^{2}>0.99\right)$ for all the 49 NMHCs. Figure S4 shows a typical chromatogram of the standard gas during the calibration experiment. Peak identification and quantification were performed using PC software (OpenLab CDS, ChemStation Edition, Rev. C.01.06(61); Agilent Technologies). Furthermore, Supplement 2 provides an example chromatogram for each source that was sampled. All the chromatograms were manually inspected to ensure correct peak identification, baseline determination and peak area calculation. The FID signal of a compound was recorded in the form of a current (picoampere - pA) by the instrument, and the area under the peak was calculated and expressed in units of pAs (picoampere seconds) and used to quantify the analyte. Individual peak areas (in pAs) were converted to parts per billion using the sensitivity factors obtained from calibration experiments. For highly concentrated samples, appropriate dilution was performed prior to the sample injection so that the measured concentrations were within the range of 5-30 ppb for most of the compounds. However, there were still a few compounds that were 50-200 ppb in some sources even after dilution (Table S2). The instrument linearity was therefore tested at high concentrations of up to $200 \mathrm{ppb}$, and excellent linearity ( $r^{2} \geq 0.99$ ) was observed for all the compounds (Fig. S3).

The Supplement 3 (in Excel file format) provides details of the measured mixing ratios for each individual sample measured by the TD-GC-FID system after dilution, mixing ratios of the compound in the actual sample after correcting for dilution along with uncertainty and the values in the corresponding background samples. For the major compounds determining the normalised source profiles (presented and discussed in Sect. 3.1), the sample values were significantly higher than the background values (even by an order of magnitude or more for smoke and vehicular exhaust source categories). Therefore, while the background values were used to calculate excess concentrations, they hardly played any role in the determination of the emission profiles. The peaks in the chromatograms of the emission sources were also well resolved and separated and were identified using the calibration gas standards. In case a shoulder peak was present, the parent peak was separately integrated, i.e., any interference from a shoulder peak was subtracted from the parent signal. In the calibration gas standard, some additional compounds were also present, namely 2,2,4-trimethylpentane, 2,3,4-trimethylpentane and methylcyclohexane, each of which had a well-resolved and separate peak during the calibration experiments. However, during the analysis of emission source samples, these compounds exhibited poor peak features like peak shape, several shoul- der peaks, etc. Therefore, to remain consistent across all samples, these compounds were excluded from the analysis, and only those compounds that were well resolved were included. Table S3 lists the details of two VOC gas standards, namely the (1) gas standard (Chemtron Science Laboratories Private Limited) containing VOCs at a mixing ratio of circa 1 parts per million by volume (ppmv; stated accuracy of $\pm 5 \%$ ) and the (2) gas standard (Apel Riemer Environmental, Inc.) containing VOCs at circa $500 \mathrm{ppb}$ (stated accuracy better than $5 \%$ ) with which the instrument was calibrated. Instrumental sensitivities can change during a long run deployment owing to a change in settings and mechanical wear and tear, and therefore, regular calibrations are important to assess the instrumental stability. Table S4 shows the average sensitivity factors (pAs/ppb) and standard deviation derived from 13 calibrations performed regularly between December 2016 and October 2018, with no major changes ( $8 \%-12 \%$ for most of the measured compounds) observed in the instrumental sensitivities. A reasonable agreement (considering the maximum instrumental uncertainty error of $<15 \%$ ) was found for the average calibration factors between December 2016 and October 2018 and derived from the two different gas standards for the common compounds, such as isoprene $\left(53.2 \pm 4.9\right.$ and $\left.55.6 \pm 5.9 \mathrm{pAs} \mathrm{ppb}^{-1}\right)$, benzene $\left(67.8 \pm 5.6\right.$ and $\left.69.2 \pm 5.5 \mathrm{pAs} \mathrm{ppb}^{-1}\right)$ and toluene $\left(74.6 \pm 6.6\right.$ and $\left.81.3 \pm 7.7 \mathrm{pAs} \mathrm{ppb}^{-1}\right)$. Table 2 lists the compound-specific precision errors, limit of detection (LOD) and total uncertainties. The precision of the instrument was evaluated under identical conditions, using the relative standard deviation of five individual measurements of 1 and $5 \mathrm{ppb}$ of the standard gas mixture, and was in the range of $1 \%-6 \%$ for $1 \mathrm{ppb}$ and $0.1 \%-0.5 \%$ for $5 \mathrm{ppb}$ of the reported compounds. The limit of detection of the instrument was evaluated according to Eq. (1) at $5 \%$ probability, using the standard deviation of eight zero/blank samples measurements under identical conditions (Penkett, 2007; ACTRIS, 2014).

$\mathrm{LOD}=2 t \sigma$

Here, $\sigma$ is the standard deviation of eight blank measurements (manual integration of peaks in the blank sample; if peaks were missing then the integration of the baseline corresponding to the same retention time and average peak width was used), and $t$ is the Student's $t$ value for the $5 \%$ probability and $7^{\circ}$ of freedom. The instrumental LOD was in the range of 2-104 parts per trillion (ppt). The total uncertainties were calculated using the root mean square propagation of individual uncertainties, like the $5 \%$ accuracy error inherent in the VOC gas standard concentration, error in the linear fit of the calibration curve, the error in the flow reproducibility of the two mass flow controllers and the precision error of the instrument. The overall uncertainties for all compounds were less than $15 \%$. 


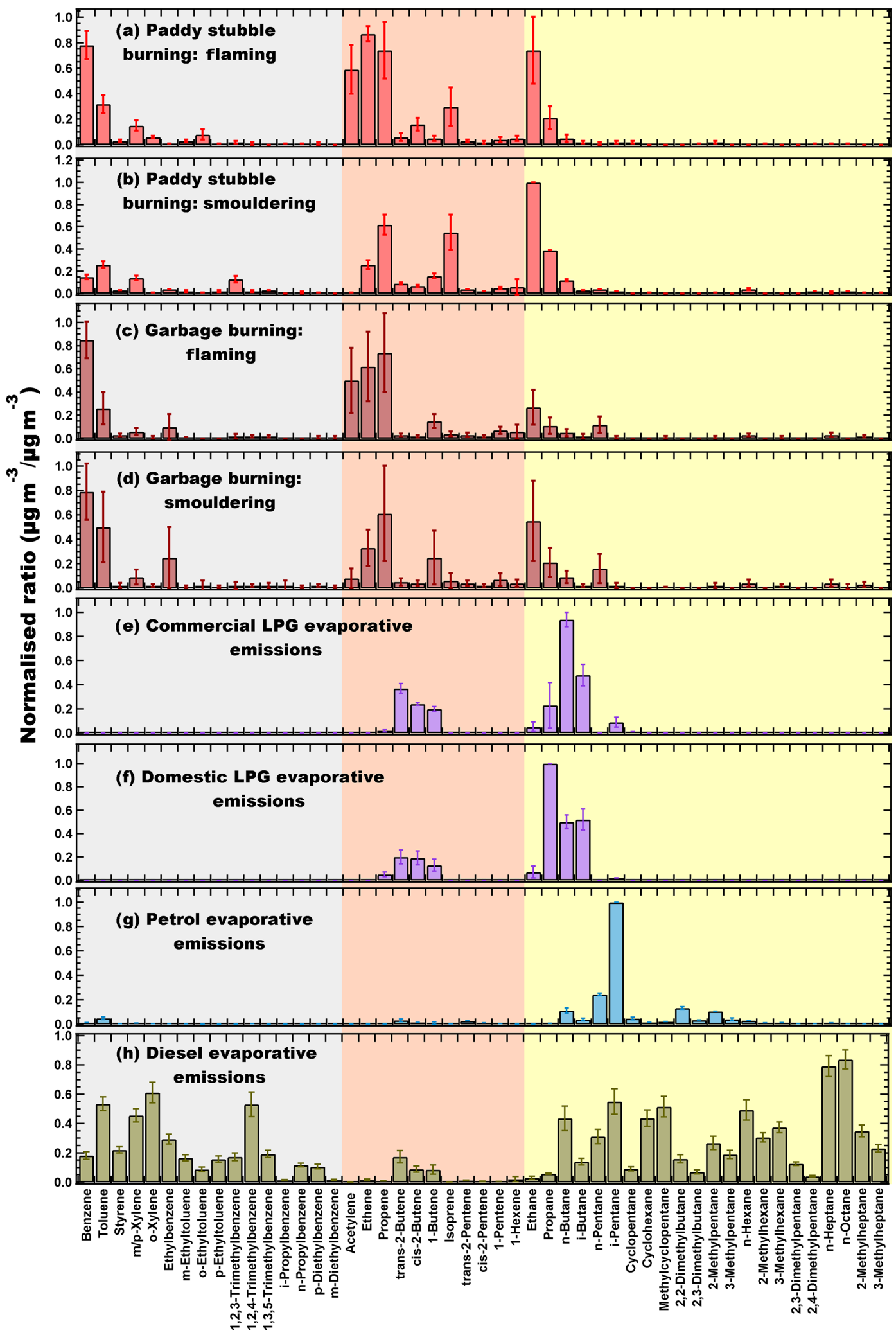

Figure 1. Normalised source profiles of (a) paddy stubble burning - flaming. (b) Paddy stubble burning - smouldering. (c) Garbage burning - flaming. (d) Garbage burning - smouldering. (e) Commercial liquefied petroleum gas (LPG) evaporative emissions. (f) Domestic LPG evaporative emissions. (g) Petrol evaporative emissions. (h) Diesel evaporative emissions derived from the thermal desorption gas chromatography flame ionisation detection (TD-GC-FID) measurements. Error bars represent the standard error of averaged normalised ratio. Grey highlights the aromatics, red the alkenes and alkyne and yellow the alkanes. 


\section{Results and discussion}

\subsection{NMHC chemical fingerprinting of emission sources}

\subsubsection{Paddy stubble fires and garbage fires}

Figure 1a-d show the normalised emission profiles of the whole air samples collected from paddy stubble and garbage fires under flaming and smouldering conditions. The mixing ratios were corrected for ambient background levels using samples collected just before the fires, normalised to the NMHC, with the maximum mass concentration in the respective source sample and averaged for the different fires.

The largest contributors to the mass concentrations in paddy fires under flaming conditions were ethene $(16 \%)$, benzene $(16 \%)$, propene $(13 \%)$, acetylene $(13 \%)$ and ethane $(12 \%)$, while in smouldering conditions ethane (21\%), isoprene $(13 \%)$, propene $(13 \%)$, propane $(8 \%)$ and ethene $(6 \%)$ were the highest ranked contributors. Acetylene was found to be negligible $(<1 \%)$ in smouldering fires and, therefore, can be used as tracer for fires under flaming conditions. Amongst alkenes, the fraction of ethene and propene reduced in smouldering while that of isoprene increased by $\sim 3$ times relative to the flaming stage emissions. In the studies reported previously (Akagi et al., 2011; Andreae, 2019), ethene was reported to have higher emissions than propene from crop residue fires. Our study results reveal that ethene emissions were lower in the smouldering fires compared to propene. While previous studies compiled the results of mostly the laboratory combustion of fuels in controlled environments that are more typical of flaming conditions, the smouldering stage of fire, which is characterised by poor combustion efficiency and therefore different flame chemistry in the agricultural fields as encountered by us, may be a cause for this variance and emphasise why results from controlled burn experiments need to be complemented with field crop residue fire results. In the garbage fire emissions, under both flaming and smouldering conditions, benzene ( $24 \%$ and $26 \%$, respectively), propene (15\% and $11 \%$, respectively) and ethene (14\% and $7 \%$, respectively) were the most dominant NMHCs. The differences in the burning efficiency of the fires were highlighted again by the lower fraction of acetylene $(\sim 1 \%)$ in smouldering conditions, while in flaming conditions it was $11 \%$. Ethane, propane and $n$ butane increased by $\sim 2$ times under smouldering conditions. The garbage burnt in this study mostly comprised of wet vegetable and food waste from households (Sharma et al., $2019)$ and, therefore, had lower styrene $(<1 \%)$ compared to garbage samples containing plastic and packaging material, which can also be a source of styrene emissions due to the presence of plastic (polystyrene) waste (Lemieux et al., 2004; Tang et al., 2000). Isoprene was found to be very low $(<1 \%)$ in the garbage fires compared to the paddy stubble fires and, therefore, could be potentially employed to distinguish paddy stubble and garbage burning activities in the absence of iso- prene emissions at night from biogenic sources. Furthermore, propane has been widely used as an emission tracer for fugitive LPG emissions (Blake and Rowland, 1995; Barletta et al., 2002; Apel et al., 2010), but in a complex emission environment influenced by intensive paddy stubble fires, the use of propane as a fugitive LPG emission tracer may not be ideal as it is one of the major species ( $8 \%$ of the total NMHC emissions) emitted from the paddy stubble burning.

\subsubsection{Fuel evaporative emissions}

Figure 1e-h show the normalised source profiles of the whole air samples collected from the headspace of liquefied petroleum gas (LPG), petrol and diesel.

Propane, $n$-butane, $i$-butane and butenes were the major constituents of LPG evaporative emissions. Remarkably, the composition was different in both the types of LPG evaporative emissions. The domestic LPG evaporative emissions were a mixture of propane and butanes, with propane $(40 \%)$ as the most dominant emission by weight, followed by $n$ butane $(19 \%)$ and $i$-butane $(16 \%)$. However, the commercial LPG evaporative emissions were mostly butane rich, with lower propane $(7 \%)$ and higher butenes $(31 \%$ in total from all isomers). $n$-butane (37\%) and $i$-butane (18\%) comprised of nearly half of the total evaporative emissions from commercial LPG cylinders. The most abundant species in petrol evaporative emissions were $i$-pentane (49\%), $n$ pentane (12\%), 2,2-dimethylbutane (6\%), 2-methylpentane $(5 \%), n$-butane $(5 \%)$ and toluene $(2 \%)$. The total aromatic content in the petrol vapours was low (4\%), which is consistent with previous studies (Harley et al., 2000; Na et al., 2004). Diesel evaporative emissions were quite different from petrol and had a high fraction of heavier $\mathrm{C}_{5}-\mathrm{C}_{8}$ alkanes $(55 \%)$ and aromatics $(36 \%)$, while unsaturated $\mathrm{C}_{2}-\mathrm{C}_{6}$ compounds comprised only about $4 \%$ of the total emissions. The alkane content in our diesel evaporative emissions was $60.6 \pm 1.8 \%$ and was comparable to the Guangzhou diesel $(53.8 \pm 10.0 \%)$, Zhuhai diesel $(57.4 \pm 5.3 \%)$ and Macau diesel (64.3 $\pm 1.6 \%$; Tsai et al., 2006) along with having the characteristic of a higher fraction of heavier alkanes and $\mathrm{C}_{8}-\mathrm{C}_{10}$ aromatics. $n$-octane $(8 \%), n$-heptane $(7 \%), o$ xylene (6\%), 1,2,4-trimethylbenzene (5\%), $i$-pentane (5\%), methylcyclopentane $(5 \%)$ and toluene $(5 \%)$ were the major species identified in diesel vapours. $\mathrm{C}_{8}$ and $\mathrm{C}_{9}$ aromatic compounds were roughly $14 \%$ each of the total emissions and constituted the major fraction of aromatic content in the diesel vapours.

\subsubsection{Vehicular exhaust and traffic emissions}

Figure 2 shows the normalised source profiles of the whole air samples collected from the exhaust tailpipe of idling vehicles with different fuel types and from busy traffic junctions. Among the NMHCs, compressed natural gas (CNG) vehicular emissions (Fig. 2a) had $70 \%$ ethane by mass concen- 


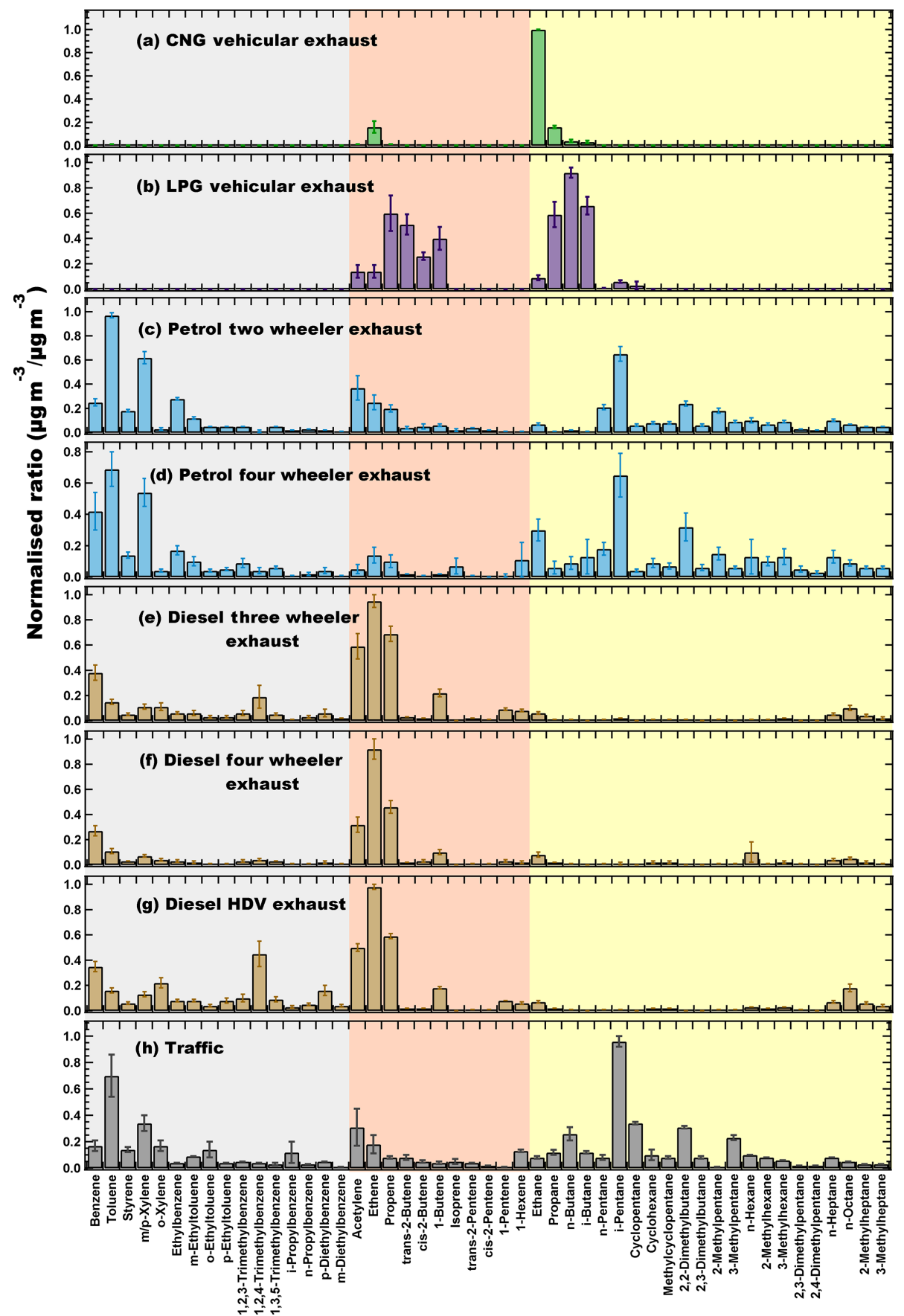

Figure 2. Normalised source profiles of (a) compressed natural gas (CNG) vehicular exhaust, (b) LPG vehicular exhaust, (c) petrol twowheeler vehicular exhaust, (d) petrol four-wheeler vehicular exhaust, (e) diesel three-wheeler vehicular exhaust, (f) diesel four-wheeler vehicular exhaust, (g) diesel heavy-duty vehicle (HDV) exhaust and (h) traffic derived from the TD-GC-FID measurements. Error bars represent the standard error of averaged normalised ratio. Grey highlights the aromatics, red the alkenes and alkyne and yellow the alkanes.

tration, which is not surprising considering that it is mostly composed of methane and ethane (Goyal and Sidhartha, 2003). The other major NMHC emissions from CNG exhaust were propane $(11 \%)$ and ethene $(10 \%)$. Overall, alkanes $(87 \%)$ and alkenes $(12 \%)$ accounted for almost all NMHC emissions from the CNG vehicles.
Figure $2 \mathrm{~b}$ shows that LPG vehicular emissions were mainly comprised of low molecular weight alkanes, i.e, $\mathrm{C}_{2}-\mathrm{C}_{4}$ NMHCs. $n$-butane (23\%), $i$-butane $(15 \%)$, propane $(13 \%)$, propene $(12 \%)$, trans-2-butene $(11 \%)$, 1-butene $(8 \%)$ and cis-2-butene $(6 \%)$ were the major components by mass concentration in these emissions. Alkanes accounted 
for $56 \%$ and alkenes $44 \%$ of the total emissions, whereas aromatics were negligible. LPG fuel is known to completely combust at higher driving speeds, and therefore the presence of propane and butanes in the exhaust was indicative of incomplete combustion at the idling stage (Guo et al., 2011). The major compounds in LPG-fuelled vehicle emissions found in this study were similar to studies in Taiwan (Chang et al., 2001) and Guangzhou (Lai et al., 2009). One major difference was that $n$-butane was the most abundant emission in the LPG vehicular exhaust in this study compared to propane, which is reported in the aforementioned studies. In Hong Kong, the LPG fuel composition shows a relative ranking of $n$-butane $>$ propane $>i$-butane (Tsai et al., 2006). However, in our evaporative emission samples, we observed propane $>n$-butane $>i$-butane for domestic LPG cylinders and $n$-butane $>i$-butane $>$ propane for commercial LPG cylinders. The differences in our observations, compared to the studies from Guangzhou (Lai et al., 2009), Taiwan (Chang et al., 2001) and Hong Kong (Guo et al., 2011), regarding the higher fraction of butanes as compared to propane in idling vehicular exhaust, could therefore be because of different engine technology/efficiency and combustion conditions in addition to the fuel composition.

Figure $2 \mathrm{c}-\mathrm{d}$ show the averaged vehicular emissions for two wheelers and four wheelers fuelled by petrol. Aromatics $(44 \%)$ and alkanes $(42 \%)$ were the major constituents of emissions from petrol vehicles, with toluene $(15 \%), i$ pentane $(11 \%), \mathrm{m} / \mathrm{p}$-xylene $(10 \%)$, benzene $(4 \%), 2,2-$ dimethylbutane $(4 \%)$ and acetylene $(4 \%)$ being the most abundant NMHC species. These results are also similar to the studies conducted in Taiwan (Chang et al., 2001) and the Pearl River Delta (Liu et al., 2008). The two-wheeler motorbikes and scooters have different motor engines compared to the four-wheeler vehicles and are known to combust the fuel inefficiently, resulting in high VOC emissions (Costagliola et al., 2014; Dröge et al., 2011; Liu et al., 2008; Tsai et al., 2014). Furthermore, they comprise nearly $73 \%$ of the registered Indian vehicular fleet (MoRTH, 2018) and dominate the emissions from the road transport sector. Therefore, we present the normalised profiles of two wheelers and four wheelers separately to understand the emission profiles and to assess their impact on regional air quality. The emissions from the tailpipes of two wheelers majorly comprised of toluene (16\%), $i$-pentane $(11 \%), \mathrm{m} / \mathrm{p}$-xylene $(10 \%)$, acetylene $(6 \%)$, ethylbenzene $(5 \%)$, benzene $(4 \%)$ and 2,2-dimethylbutane $(4 \%)$. These NMHCs were also present in the emissions from four-wheeler vehicles, which were comprised of toluene $(13 \%), i$-pentane $(10 \%), \mathrm{m} / \mathrm{p}$ xylene $(10 \%)$, benzene (7\%), 2,2-dimethylbutane $(5 \%)$ and ethane $(5 \%)$. Higher fractions of $\mathrm{C}_{2}-\mathrm{C}_{4}$ alkanes were measured in four wheelers and were primarily dominated by ethane. A high content of BTEX (34\%) in petrol exhaust emissions is also noteworthy, considering their potential impact on air quality and human health.
Figure $2 \mathrm{e}-\mathrm{g}$ show the tailpipe emissions from light-duty three wheelers, light-duty four wheelers and heavy-duty vehicles fuelled by diesel. The diesel exhaust emission profiles were much simpler than the petrol exhaust emissions. Alkenes and acetylene were the major constituents of the diesel vehicular exhaust, contributing $58 \%$ to the total NMHC emissions. Furthermore, the BTEX (16\%) and $\mathrm{C}_{6}$ $\mathrm{C}_{8}(8 \%)$ emissions were also lower than the petrol exhaust emissions. Diesel engines are known for their better combustion efficiency (Reiter and Kockelman, 2016), due to which most of the higher hydrocarbons are combusted and yield the characteristic source profile of diesel exhaust containing ethene $(26 \%)$, propene $(14 \%)$ and acetylene $(11 \%)$ by weight percent (Liu et al., 2008; Schauer et al., 1999). There were no major differences in the profiles of the different types of diesel vehicles and ethene, propene, acetylene, benzene, 1,2,3-trimethylbenzene and 1-butene were the most dominant NMHCs. However, the fraction of $\mathrm{C}_{9}-\mathrm{C}_{10}$ aromatics was higher in heavy-duty vehicles $(19 \%)$ and three wheelers $(11 \%)$ compared to four wheelers $(6 \%)$. Since $i$-pentane was found to be negligible $(<0.5 \%)$ in diesel exhaust, it was identified as an ideal tracer for petrol vehicular emissions, as has also been reported previously (Tsai et al., 2006; Guo et al., 2011).

In comparison to petrol, the diesel exhaust had lower fraction of heavier $\mathrm{C}_{6}-\mathrm{C}_{8}$ alkanes $(8 \%)$, which were likely combusted. Figure $2 \mathrm{~h}$ shows the averaged source profile of the whole air sample collected from three busy traffic junctions which therefore represent the ambient traffic emissions mixture. Although the Indian vehicular fleet comprises vehicles running on petrol, diesel, LPG and CNG, more than $70 \%$ of on-road vehicles are petrol fuelled (Guttikunda and Mohan, 2014; Goel and Guttikunda, 2015; Prakash and Habib, 2018). Therefore, the petrol vehicular exhaust emissions were expected to dominate the ambient traffic mixing ratios. As the samples were collected during rush hour (afternoon and evening hours) within some of the busiest traffic thoroughfares in two cities (Chandigarh and Mohali) as mentioned in Table 1 , the samples were influenced by a sufficiently diverse fleet mixture similar to most Indian cities. The sampling duration in each case was $\sim 15 \mathrm{~min}$; therefore, they are not biased by few individual vehicles and can be considered to be representative of the ambient city traffic emissions. These samples are not representative of highway emissions which, on the other hand, tend to be dominated by light-duty diesel vehicles and heavy-duty diesel vehicles. While more samples collected in other seasons in addition to spring would have been better, as combustion as environmental conditions can affect variability of emissions, changes in terms of the major compound mixture emitted are unlikely. In addition, since the traffic samples were collected from busy traffic junctions, these were more likely to be influenced by the emissions in the vehicular idling condition, as discussed earlier. Alkanes $(51 \%)$ and aromatics $(34 \%)$ formed a major fraction of the traffic emissions. Major NMHC species measured 
Table 2. Compound-specific precision errors (\%), limit of detection (LOD; in parts per trillion - ppt) and total measurement uncertainties (\%). Note: $\mathrm{ppb}$ - parts per billion.

\begin{tabular}{|c|c|c|c|c|c|c|c|c|c|}
\hline Compounds & $\begin{array}{r}\text { Precision } \\
\text { at } 1 \mathrm{ppb} \\
(\%)\end{array}$ & $\begin{array}{r}\text { Precision } \\
\text { at } 5 \mathrm{ppb} \\
(\%)\end{array}$ & $\begin{array}{l}\text { LOD } \\
\text { (ppt) }\end{array}$ & $\begin{array}{r}\text { Uncertainty } \\
(\%)\end{array}$ & Compounds & $\begin{array}{r}\text { Precision } \\
\text { at } 1 \mathrm{ppb} \\
(\%)\end{array}$ & $\begin{array}{r}\text { Precision } \\
\text { at } 5 \mathrm{ppb} \\
(\%)\end{array}$ & $\begin{array}{l}\text { LOD } \\
\text { (ppt) }\end{array}$ & $\begin{array}{r}\text { Uncertainty } \\
(\%)\end{array}$ \\
\hline \multicolumn{10}{|l|}{ Aromatics $(n=16)$} \\
\hline Benzene & 1 & 0.2 & 21 & 5.9 & $p$-Ethyltoluene & 1 & 0.3 & 9 & 9.3 \\
\hline Toluene & 2 & 0.3 & 87 & 6.2 & 1,2,3-Trimethylbenzene & 2 & 0.2 & 104 & 11.3 \\
\hline Styrene & 2 & 0.4 & 19 & 7.0 & $1,2,4$-Trimethylbenzene & 1 & 0.2 & 56 & 9.0 \\
\hline$m / p$-Xylene & 1 & 0.1 & 45 & 7.1 & $1,3,5$-Trimethylbenzene & 3 & 0.2 & 14 & 9.0 \\
\hline$o$-Xylene & 2 & 0.2 & 24 & 5.8 & $i$-Propylbenzene & 2 & 0.3 & 7 & 6.6 \\
\hline Ethylbenzene & 1 & 0.3 & 41 & 6.5 & $n$-Propylbenzene & 1 & 0.2 & 8 & 8.0 \\
\hline$m$-Ethyltoluene & 1 & 0.4 & 9 & 8.8 & $m$-Diethylbenzene & 1 & 0.1 & 5 & 12.3 \\
\hline$o$-Ethyltoluene & 2 & 0.3 & 9 & 8.9 & $p$-Diethylbenzene & 2 & 0.1 & 17 & 14.7 \\
\hline \multicolumn{10}{|l|}{ Alkyne $(n=1)$} \\
\hline Acetylene & 5 & 0.2 & 64 & 5.9 & & & & & \\
\hline \multicolumn{10}{|l|}{ Alkenes $(n=10)$} \\
\hline Ethene & 6 & 0.3 & 103 & 5.9 & Isoprene & 3 & 0.2 & 4 & 6.0 \\
\hline Propene & 4 & 0.3 & 47 & 5.8 & 1-Pentene & 2 & 0.1 & 2 & 5.8 \\
\hline 1-Butene & 3 & 0.2 & 3 & 5.8 & trans-2-Pentene & 1 & 0.2 & 4 & 5.8 \\
\hline trans-2-Butene & 2 & 0.3 & 18 & 6.0 & cis-2-Pentene & 2 & 0.2 & 2 & 5.8 \\
\hline cis-2-Butene & 1 & 0.2 & 8 & 5.8 & 1-Hexene & 2 & 0.3 & 4 & 5.8 \\
\hline \multicolumn{10}{|l|}{ Alkanes $(n=22)$} \\
\hline Ethane & 3 & 0.3 & 15 & 7.3 & $n$-Hexane & 2 & 0.5 & 3 & 5.8 \\
\hline Propane & 5 & 0.2 & 20 & 5.8 & 2-Methylpentane & 1 & 0.2 & 2 & 5.8 \\
\hline$n$-Butane & 2 & 0.1 & 3 & 5.8 & 3-Methylpentane & 1 & 0.2 & 3 & 5.8 \\
\hline$i$-Butane & 4 & 0.2 & 6 & 5.8 & 2-Methylhexane & 2 & 0.2 & 15 & 5.8 \\
\hline$i$-Pentane & 2 & 0.2 & 4 & 7.3 & 3-Methylhexane & 2 & 0.3 & 7 & 5.8 \\
\hline$n$-Pentane & 1 & 0.1 & 4 & 5.8 & 2,3-Dimethylpentane & 1 & 0.1 & 1 & 5.8 \\
\hline Cyclopentane & 1 & 0.2 & 3 & 6.3 & 2,4-Dimethylpentane & 2 & 0.2 & 11 & 5.8 \\
\hline Cyclohexane & 1 & 0.2 & 2 & 5.8 & $n$-Heptane & 2 & 0.3 & 15 & 5.9 \\
\hline Methylcyclopentane & 2 & 0.3 & 13 & 5.8 & $n$-Octane & 3 & 0.2 & 103 & 5.8 \\
\hline 2,2-Dimethylbutane & 2 & 0.2 & 4 & 5.8 & 2-Methylheptane & 2 & 0.2 & 85 & 5.8 \\
\hline 2,3-Dimethylbutane & 1 & 0.1 & 2 & 5.8 & 3-Methylheptane & 4 & 0.2 & 81 & 5.8 \\
\hline
\end{tabular}

from the traffic were $i$-pentane $(15 \%)$, toluene $(11 \%), n$ pentane $(5 \%), m / p$-xylene $(5 \%), 2,2$-dimethylbutane $(5 \%)$ and acetylene (4\%).

Based on the emission characteristics discussed earlier for each fuel type, petrol vehicles and LPG vehicles were identified as being the most likely sources of $i$-pentane and propane, respectively, in the traffic plume. Even though the Indian vehicular fleet is dominated by petrol-fuelled vehicles, the consumption of diesel in the road transport sector is approximately twice as much as petrol (Sadavarte and Venkataraman, 2014; Prakash and Habib, 2018). This is because the maximum diesel consumption $(40 \%)$ is by heavyduty vehicles (HDVs) which run over large distances across intercity highways and have lower mileage than other vehicle classes.

In the past three decades, India has undergone rapid economic and industrial growth, which in turn has resulted in increased consumption of diesel to sustain the increased freight transport across the country (Nielsen, 2013). As discussed previously, the diesel vehicular exhaust and evaporative emissions were dominated by heavier $\mathrm{C}_{6}-\mathrm{C}_{8}$ alkanes, alkenes and aromatics, which are key precursors in $\mathrm{OH}$ reactivity and ozone formation. Furthermore, secondary organic aerosols (SOAs) formed from the diesel vehicular exhaust are estimated to be 2-7 times more than petrol vehicular exhaust in urban areas where diesel generally accounts for $10 \%-30 \%$ of total on-road fuel consumption (Gentner et al., 2012).

It was estimated that in 2009 the transport sector contributed $694 \mathrm{Gg}$ of particulate matter (PM) emissions in India, $>70 \%$ of which came from vehicles fuelled by diesel (Sahu et al., 2014). Since LPG and CNG vehicular emissions are mostly comprised of $\mathrm{C}_{2}-\mathrm{C}_{4}$ alkanes and alkenes, they have lower SOA formation potentials than petrol and diesel (Derwent et al., 2010) and, therefore, have emerged as cleaner fuel alternatives. However, the emission of a large 
suite of reactive unsaturated NMHCs due to improper combustion of these fuels results in high OH reactivity and OFP, which can severely impact local air chemistry and quality. Therefore, in order to mitigate the emissions, the use of improved technologies (for better combustion and emission reduction, like catalytic convertors), cleaner fuels (Bharat stage V (BSV) and Bharat stage VI (BSVI); GoI, 2016) and reduced idling times of the vehicles should be encouraged. Also, depending on which type of pollution is more acute (PM or gaseous), promoting the appropriate less-polluting fuel type for more usage could help to reduce the overall ambient pollution.

\subsection{Assessment of $\mathrm{OH}$ reactivity, ozone formation potential (OFP) and BTEX loading from different emission sources}

Figure $3 \mathrm{a}-\mathrm{d}$ show the comparison of the percentage contribution of different chemical classes of NMHCs to the total mass concentrations, $\mathrm{OH}$ reactivity $\left(\mathrm{s}^{-1}\right)$, normalised reactivity $\left(\mathrm{gO}_{3} / \mathrm{gNMHC}\right)$ and total BTEX loading (\%) from various emission sources. The hydroxyl radical reactivity reflects the total pollutant loading of the air mass (Sinha et al., 2012) and was calculated using Eq. (2) as follows:

Total NMHC OH reactivity $=\Sigma k_{\mathrm{OH}+\mathrm{NMHCi}}\left[\mathrm{NMHC}_{i}\right]$,

where $k_{\mathrm{OH}+\mathrm{NMHCi}}$ is the first-order rate coefficient for the reaction of $\mathrm{NMHC}_{i}$ with $\mathrm{OH}$ radicals (Atkinson et al., 1982, 2006), and $\left[\mathrm{NMHC}_{i}\right]$ is the measured concentration of the NMHC.

The ozone formation potential (OFP) is used as a metric to measure the contribution of NMHCs to the total $\mathrm{O}_{3}$ formation potential in urban environments (Carter, 1994). Normalised reactivity $R$ ( $\mathrm{gO}_{3} / \mathrm{gNMHCs}$ emitted) is generally used to indicate OFP for NMHCs from emission sources using their source profiles and maximum incremental reactivity (MIR) values, using Eq. (3) as follows (Harley et al., 2000; Zhang et al., 2013):

$R=\Sigma_{i} \omega_{i} \times\left(\mathrm{MIR}_{i}\right)$,

where $\omega i$ are the weight percentage of $\mathrm{NMHC}_{i}$ present in the emission source, and $\mathrm{MIR}_{i}$ are the maximum incremental reactivity coefficients (Carter, 1994, 2009).

In order to ascertain any statistical difference between the average OFPs of the emission sources, we carried out Tukey's pairwise honestly significant difference test (which accounts for sample size), and the summary of the test results is provided in Table S5. Based on the statistical test, it could be concluded with more than $95 \%$ confidence that $\mathrm{CNG}$ vehicular emissions and the fuel evaporative emissions had different OFPs compared to other emission sources. The averaged OFP for the emission sources was diesel vehicle exhaust $\left(6.5 \pm 0.6 \mathrm{gO}_{3} / \mathrm{gNMHC}\right)$, smouldering paddy stubble fire $\left(5.9 \pm 0.2 \mathrm{gO}_{3} / \mathrm{gNMHC}\right)$,
LPG vehicle exhaust $\left(5.7 \pm 1.1 \mathrm{gO}_{3} / \mathrm{gNMHC}\right)$, flaming paddy stubble fire $\left(5.2 \pm 0.9 \mathrm{gO}_{3} / \mathrm{gNMHC}\right)$, flaming garbage fire $\left(4.9 \pm 1.1 \mathrm{gO}_{3} / \mathrm{gNMHC}\right)$, smouldering garbage fire $\left(4.4 \pm 1.3 \mathrm{gO}_{3} / \mathrm{gNMHC}\right)$, LPG evaporative emissions $\left(4.5 \pm 1.6 \mathrm{gO}_{3} / \mathrm{gNMHC}\right)$, petrol vehicle exhaust $\left(3.9 \pm 0.7 \mathrm{gO}_{3} / \mathrm{gNMHC}\right)$, diesel evaporative emissions $\left(3.6 \pm 0.9 \mathrm{gO}_{3} / \mathrm{gNMHC}\right)$, petrol evaporative emissions $\left(2.0 \pm 0.4 \mathrm{gO}_{3} / \mathrm{gNMHC}\right)$ and $\mathrm{CNG}$ vehicle exhaust $\left(1.5 \pm 0.8 \mathrm{gO}_{3} / \mathrm{gNMHC}\right)$. Although, alkenes were not the largest emissions by mass, they were still the largest contributor to the $\mathrm{OH}$ reactivity $(67 \%-93 \%)$ and OFP (70\%-83\%) in the fire and LPG evaporative emissions. In the paddy stubble and garbage fire emissions, alkenes and aromatics had the largest contribution to the total $\mathrm{OH}$ reactivity $(\sim 90 \%$ and $6 \%-9 \%$, respectively) and OFP ( $70 \%-82 \%$ and $16 \%-27 \%$, respectively). Alkanes have comparatively poor reactivity towards $\mathrm{OH}$ radical, and therefore, despite contributing $15 \%-37 \%$ to the total NMHC mass concentration, their contribution to the $\mathrm{OH}$ reactivity was very low $(<3 \%)$.

In paddy stubble fires under flaming conditions, propene (33\%), and under smouldering conditions, isoprene (46\%), were the largest contributors to the total $\mathrm{OH}$ reactivity (details in Figure S5 and S6). These two NMHCs were also the largest contributors ( $\sim 40-50 \%$ in total) to the OFP from paddy stubble fires. In garbage fires under both flaming and smouldering conditions, propene was the largest contributor to the $\mathrm{OH}$ reactivity ( $46 \%$ and $42 \%$, respectively) and OFP (37\% and $30 \%$, respectively).

LPG evaporative and vehicular exhaust emissions comprised of $68 \%-81 \%$ and $56 \%$ alkanes, respectively; however, $>90 \%$ of total $\mathrm{OH}$ reactivity was contributed by the alkenes. Butenes were the largest contributors to total $\mathrm{OH}$ reactivity from domestic LPG evaporative, commercial LPG evaporative and LPG vehicular exhaust emissions $(90 \%$, $79 \%$ and $72 \%$, respectively) and OFP (71\%, 83\% and 59\%, respectively). A total of $81 \%$ of NMHC emissions from CNG vehicular exhaust were $\mathrm{C}_{2}-\mathrm{C}_{3}$ alkanes, but the maximum contribution to the total $\mathrm{OH}$ reactivity and OFP was from ethene ( $47 \%$ and $62 \%$, respectively).

In diesel evaporative emissions there was approximately equal contribution to the total $\mathrm{OH}$ reactivity from alkanes $(36 \%)$ and aromatics (44\%). This is because of the presence of larger fractions of heavier $\mathrm{C}_{5}-\mathrm{C}_{8}$ branched alkanes, which are generally more reactive towards $\mathrm{OH}$ radicals compared to the light $\mathrm{C}_{2}-\mathrm{C}_{4}$ alkanes. While the rate coefficient values of $\mathrm{C}_{2}-\mathrm{C}_{4}$ alkanes vary between $(0.25-2.12) \times 10^{-12} \mathrm{~cm}^{3}$ molecule ${ }^{-1} \mathrm{~s}^{-1}$ at $298 \mathrm{~K}$, the rate coefficient values of $\mathrm{C}_{5}-\mathrm{C}_{8}$ alkanes are between (3.6-8.9) $\times 10^{-12} \mathrm{~cm}^{3}$ molecule $^{-1} \mathrm{~s}^{-1}$ at $298 \mathrm{~K}$. The largest contributors to the total $\mathrm{OH}$ reactivity were the trans-2-butene (10\%) and 1,2,4-trimethylbenzne $(9 \%)$, while 1,2,4-trimethylbenzene $(13 \%)$ and $o$-xylene (12\%) dominated the OFP from diesel evaporative emissions. $\mathrm{OH}$ reactivity from diesel vehicular exhaust emissions, however, were dominated by alkenes $(>75 \%)$, and 

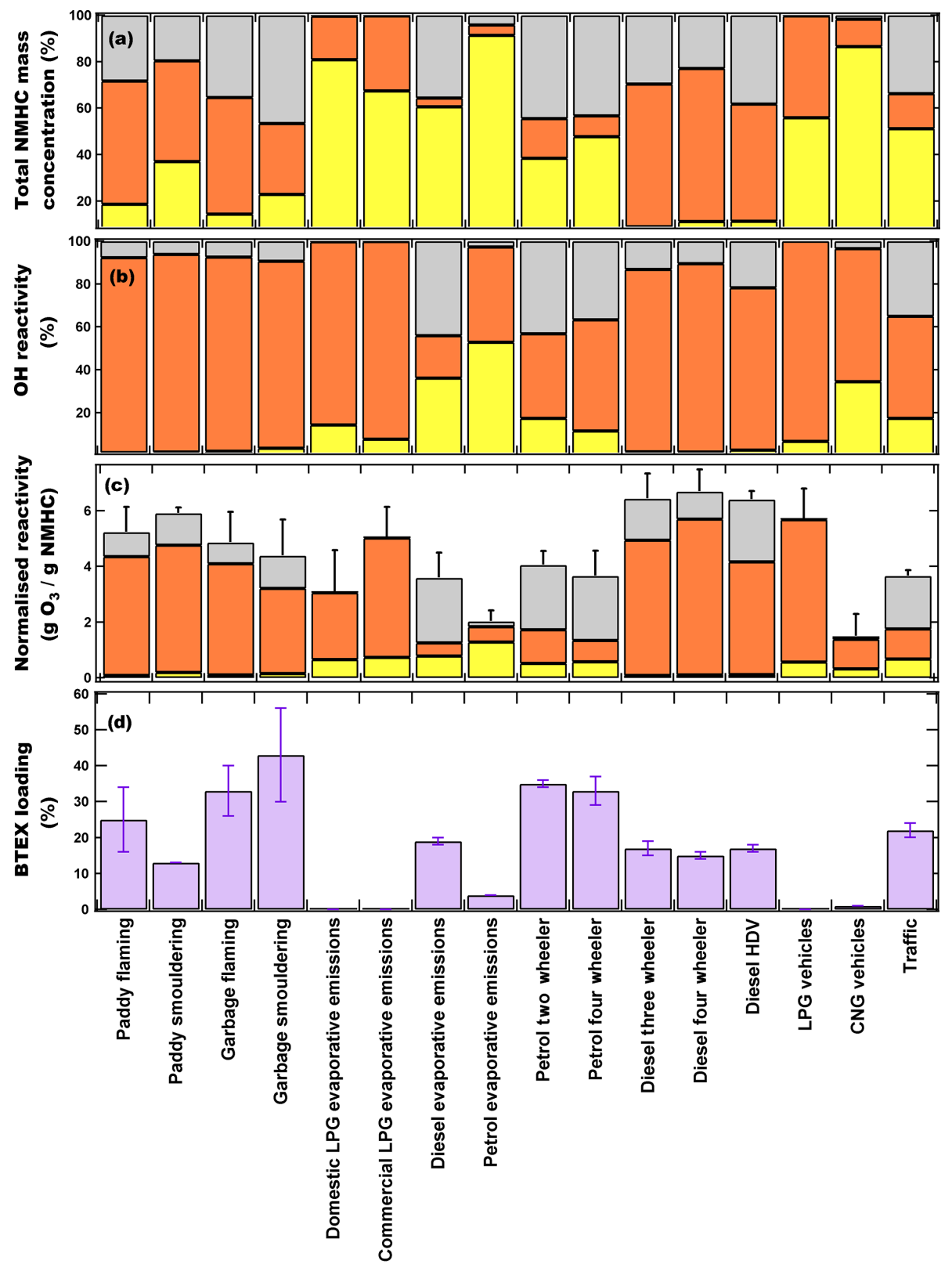

\section{Aromatics $\square$ Alkenes and alkyne $\square$ Alkanes}

Figure 3. Comparison of the contribution of chemical compositions in groups (aromatics, alkene and alkyne and alkanes) to (a) NMHC mass concentrations, (b) $\mathrm{OH}$ reactivity $\left(\mathrm{s}^{-1}\right)$ and (c) normalised reactivity $\left(\mathrm{gO}_{3} / \mathrm{gNMHC}\right)$. (d) Benzene, toluene, ethylbenzene and xylenes (BTEX) loading (\%) from various emission sources. Error bars represent the standard error of average ozone formation potential (OFP) and BTEX fraction.

propene $(32 \%-39 \%)$ and ethene $(23 \%-31 \%)$ were the largest contributors in all the diesel vehicle categories. Both of these NMHCs also contributed $>50 \%$ to the total OFP calculated from diesel vehicular exhaust. In petrol evaporative emissions, the largest contribution to the $\mathrm{OH}$ reactivity was $i$-pentane $(\sim 30 \%)$, pentene $(22 \%)$ and butene $(20 \%)$ isomers. However, in petrol vehicular exhaust both aromatics and alkenes became the dominant contributors
( $\sim 40 \%-50 \%$ each) to $\mathrm{OH}$ reactivity and the major contributors were propene $(14 \%-23 \%), m / p$-xylene $(11 \%-13 \%)$, styrene $(8 \%-11 \%)$, ethene $(6 \%-13 \%)$ and toluene $(7 \%)$. For OFP from petrol vehicular exhausts, the largest contributing NMHCs were $m / p$-xylene $(24 \%-26 \%)>$ toluene $(14 \%-16 \%)>$ propene $(5 \%-9 \%)>$ ethene $(6 \%-9 \%)$.

The total $\mathrm{OH}$ reactivity from traffic emissions was dominated by alkenes $(48 \%)$ and aromatics $(35 \%)$. The NMHCs 
contributing the largest fractions to the total $\mathrm{OH}$ reactivity were styrene $(9 \%)>$ trans-2-butene $(9 \%)>$ isoprene $(7 \%)>1$-hexene $(6 \%) \sim m / p$-xylene $(6 \%) \sim$ propene $(6 \%)$ and to OFP were $m / p$-xylene $(14 \%)>$ toluene $(12 \%)>1,2,4$-trimethylbenzene $(7 \%) \sim$ ethene $(7 \%)>i$ pentane $(6 \%)$. High contributions to $\mathrm{OH}$ reactivity from styrene, isoprene and 1-hexene are noteworthy. Even though these compounds were not the most abundant in the traffic samples by mass concentration, they are, however, very reactive with hydroxyl radicals in ambient air (isoprene $-k_{\mathrm{OH}}=10.0 \times 10^{-11} \mathrm{~cm}^{3}$ molecule $^{-1} \mathrm{~s}^{-1}$; styrene $-k_{\mathrm{OH}}=5.8 \times 10^{-11} \mathrm{~cm}^{3}$ molecule ${ }^{-1} \mathrm{~s}^{-1}$; 1-hexene $-k_{\mathrm{OH}}=3.7 \times 10^{-11} \mathrm{~cm}^{3}$ molecule ${ }^{-1} \mathrm{~s}^{-1}$ at $298 \mathrm{~K}$; Atkinson et al., 1989; Atkinson, 1997). Isoprene, styrene and 1-hexene have been reported previously in various traffic and tunnel experiments across the world (Mugica et al., 1998; Borbon et al., 2001; Barletta et al., 2002; Ho et al., 2009; Zhang et al., 2018). Our traffic samples have comparable mixing ratios of isoprene observed from roadside ambient air measurements in Karachi (1.2 \pm 0.9 ppb; Barletta et al., 2002), 43 Chinese cities $(0.86 \pm 0.83 \mathrm{ppb}$; Barletta et al., 2005) and Longchuan tunnel, Hefei $(0.47 \pm 0.20 \mathrm{ppb}$; Deng et al., 2018), but higher than Chapultepec Avenue tunnel, Mexico City (0.17 $\pm 0.02 \mathrm{ppb}$; Mugica et al., 1998), and the Fu Gui Mountain tunnel (0.14 $\pm 0.36 \mathrm{ppb}$; Zhang et al., 2018). In the Hong Kong tunnel experiment (Ho et al., 2009) and Taipei tunnel experiment (Hwa et al., 2002), isoprene was, however, undetectable. This variability in isoprene emissions from traffic/vehicular exhaust has been previously attributed to variable fuel types, vehicular engines and maintenance, driving patterns and sampling strategies.

The mixing ratios of styrene and 1-hexene measured in our traffic samples were higher than the Fu Gui Mountain tunnel (styrene $-0.08 \pm 0.00 \mathrm{ppb}$; 1-hexene $-0.07 \pm 0.00 \mathrm{ppb}$ ) but comparable to 1-hexene reported from Taiwan tunnels (Cross Harbour tunnel $(0.99 \pm 0.20 \mathrm{ppb})$, Chung-Bor tunnel (3.29 $\pm 2.36 \mathrm{ppb})$ and Chung-Cheng tunnel (2.49 $\pm 1.27 \mathrm{ppb}$; Chen et al., 2003). Though high mixing ratios of styrene are remarkable, it has been previously reported that styrene is one of the major VOCs emitted from diesel light-duty vehicles (LDVs), especially in cold transient mode (Tsai et al., 2012). Amongst our traffic samples, maximum mixing ratios of isoprene $(1.11 \pm 0.06 \mathrm{ppb})$, styrene $(2.31 \pm 0.16 \mathrm{ppb})$ and 1-hexene $(2.38 \pm 0.14 \mathrm{ppb})$ were observed in Transport Chowk $\left(30.717^{\circ} \mathrm{N}, 76.812^{\circ} \mathrm{E}\right)$ which is one of the busiest traffic junction in Chandigarh during rush hours and witnesses a large vehicular fleet of diesel-run commercial LDVs.

In order to assess the health risks associated with these sources, we compared the fraction of BTEX compounds in each of the emission sources. Benzene is classified as a human carcinogen (IARC, 2012), the potential health risk assessments of which have already been elucidated in NWIGP during the periods influenced by intense paddy stubble fires (Chandra and Sinha, 2016). Other benzenoids like toluene and xylenes have also been associated with adverse effects on human health (ATSDR, 2000, 2007) and are classified as group "D" carcinogens by the US Environmental Protection Agency (EPA). Using the BTEX fraction, which is a well-known metric (Słomińska et al., 2014), is useful for comparing the mass fractional BTEX content of the emission sources. The statistical differences in the average BTEX fraction between the different emission sources were ascertained by Tukey's pairwise honestly significant difference test, and the summary for this information is provided in Table S6. Based on the statistical test, it could be concluded with more than $95 \%$ confidence that diesel and petrol evaporative emissions, diesel vehicles and smouldering paddy fires had different average BTEX fractions compared to other emission sources. Out of 28 possible pairwise comparisons, 14 pairs show statistically significant differences with $\geq 2 \sigma$ confidence, three are only significant at $1 \sigma$ level and the rest were not significant. The fraction of BTEX in the different emission sources was petrol vehicle exhaust $(27 \pm 5 \%)$, smouldering garbage fire $(26 \pm 1 \%)$, flaming garbage fire $(24 \pm 8 \%)$, flaming paddy stubble fire $(22 \pm 5 \%)$, diesel vehicle exhaust $(19 \pm 2 \%)$, diesel evaporative emissions $(17 \pm 2 \%)$, smouldering paddy stubble fire $(13 \pm 1 \%)$ and petrol evaporative emissions $(3 \pm 1 \%)$. LPG and $\mathrm{CNG}$ emission sources had $<1 \%$ of benzene and, therefore, were identified as least harmful sources, while petrol vehicular exhaust, garbage fires and paddy stubble fires were the most toxic emissions which could severely impact human health considering their BTEX emission potential.

\subsection{Molar emission ratios of NMHCs in different emission sources}

Inter-NMHC molar ratios ( $\mathrm{ppb} / \mathrm{ppb}$ ) are very useful tools that can not only be used to distinguish between different emission sources but also constrain the identity of the sources affecting ambient mixing ratios in a complex environment (Barletta et al., 2005, 2017). This is because, for the NMHC species with similar chemical lifetimes, the molar ratios remain preserved during chemical oxidation and ambient dilution (Parrish et al., 1998; Jobson et al., 1999). Furthermore, NMHC molar ratios that remain similar across sources can also be employed to assess the photochemical age of air masses.

Table 3 lists the commonly used inter-NMHC molar emission ratios for the emission sources studied in this work. The toluene / benzene ( $\mathrm{T} / \mathrm{B}$ ) ratio is a widely used ratio in identifying vehicular emission sources (Barletta et al., 2002, 2005). The T / B measured for traffic in this study was $3.54 \pm 0.21$ which is comparable to previous studies from busy traffic junctions in Karachi $(2.2 \pm 2.9$; Barletta et al., 2002), Hong Kong (3.0 \pm 0.4 ; Huang et al. 2015), Okhla, New Delhi (2.3 \pm 1.7 ; Hoque et al. 2008), Antwerp, Belgium (3.5 \pm 0.2; Buczynska et al. 2009), and Nanjing, China (2.6 \pm 0.9 ; Wang et al. 2008). For the idling vehicular exhausts of different fuel types, this ratio varied between 0.38 


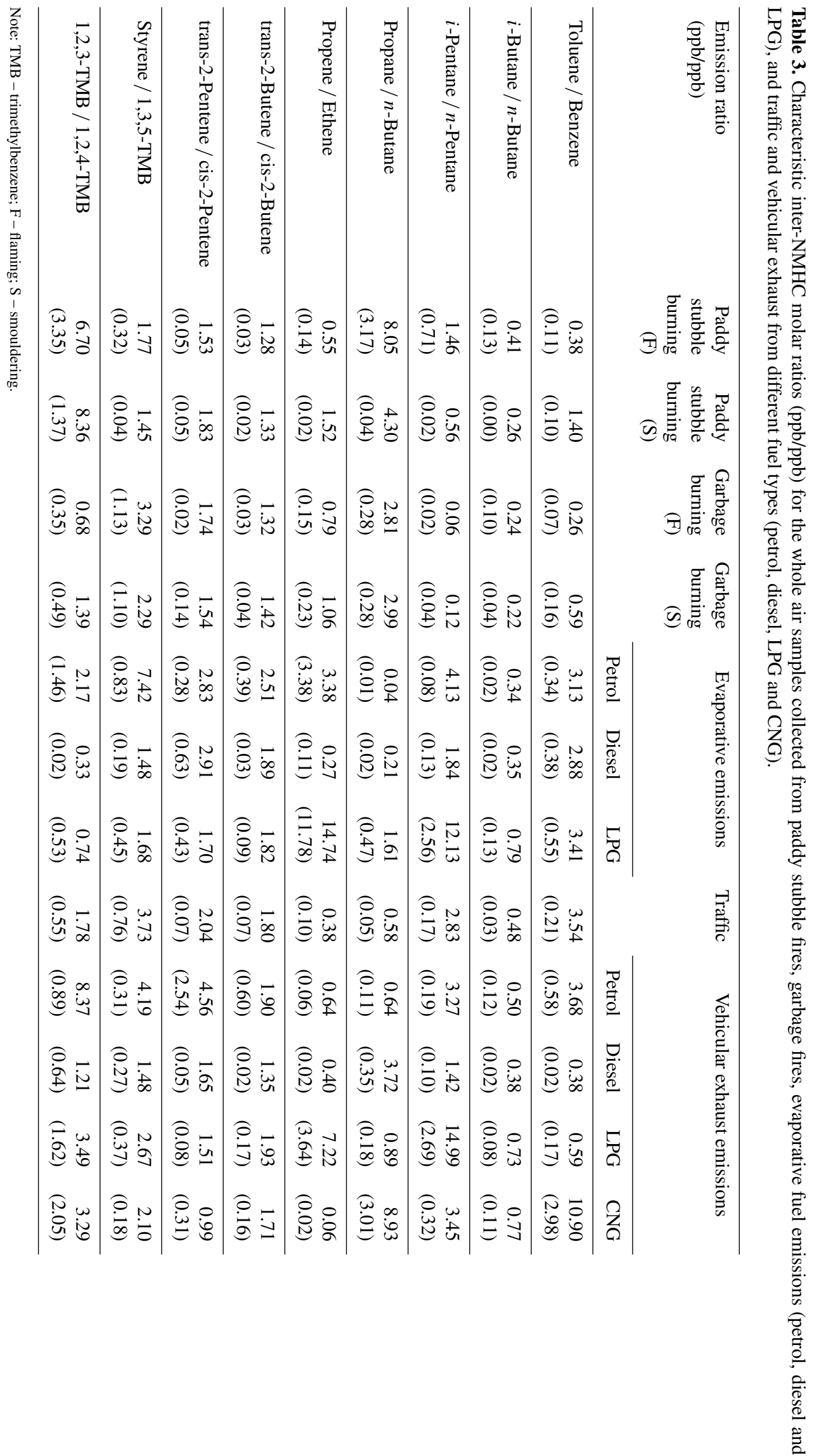


and 10.9 and was $3.68 \pm 0.58$ for petrol vehicles, which is consistent with the previous works of Guo et al. $(2011 ; 2.0$ 3.8). For the diesel vehicles, the $\mathrm{T} / \mathrm{B}$ ratio in our study was $0.37 \pm 0.20$, which is similar to the average $\mathrm{T} / \mathrm{B}$ ratio $(0.37)$ from diesel vehicles in Australia (Anyon et al., 2003), Germany (0.56; Siegl et al., 1999) and Tokyo (0.3; Yamamoto et al., 2012). Furthermore, T / B ratios can also be useful for distinguishing the paddy stubble fire emissions in the flaming $(0.38 \pm 0.11)$ and smouldering stages $(1.40 \pm 0.10)$.

The $i$-butane / $n$-butane ratio (B / B) is another example of a widely used NMHC ratio for distinguishing between different fossil-fuel-related emission sources. However, in our study, we found that this ratio is not useful in a complex emission environment influenced by varied emission sources. This is because the ratio exhibits similar values $(0.20-0.30)$ for paddy stubble fires, garbage fires, petrol evaporative, diesel evaporative and petrol vehicle exhaust and diesel vehicle exhaust emissions. Therefore, caution should be taken while using this ratio in complex emission environments where biomass burning, fossil fuel combustion and biogenic emission sources simultaneously occur on a significant scale and strength to contribute to the chemical composition of ambient air. $i$-pentane / $n$-pentane can, instead, be used as a more reliable ratio for distinguishing biomass burning emissions (0.06-1.46) from the petrol dominated traffic and fossil fuel emissions (2.83-4.13).

\section{Conclusions}

Comprehensive chemical speciation source profiles of 49 NMHCs (22 alkanes, 16 aromatics, 10 alkenes and one alkyne) were obtained for several major emission sources, namely paddy stubble burning, garbage burning, idling vehicular exhaust and evaporative fuel emissions. Many of these compounds, like the higher $\mathrm{C}_{6}-\mathrm{C}_{8}$ alkanes, $\mathrm{C}_{9}-\mathrm{C}_{10}$ aromatics and alkenes, have been quantified for the first time for these emission sources in the South Asian region, which is important for ascertaining the region-to-region variability of such common urban and agricultural emission sources. The work highlights the importance of identifying the local emission source profiles, as some NMHC emissions were found to be very different to the studies reported from North America, Europe and East Asia. Some of the major findings which provide new insights are as follows:

i. Propane was found to be one of the abundant NMHC compounds in paddy stubble fire emissions. This is in contrast to the existing literature which considers it as a tracer for fugitive LPG emissions. In a complex emission environment influenced by several sources like paddy fires, the use of propane as an LPG tracer therefore calls for caution.

ii. Propene emissions in smouldering fires were found to be more than ethene by $\sim 1.6$ times, which is in contrast to the existing crop residue burning inventories which have ethene as the more abundant compound.

iii. Isoprene was identified as a reliable tracer for distinguishing between the paddy fires and garbage fires at night.

iv. Compositional differences in the evaporative emissions from the two types of LPG (commercial and domestic) used widely in South Asia were also identified. While propane was the most dominant NMHC in the domestic LPG vapours, the commercial LPG vapours were dominated by butanes.

v. Toluene / benzene ratios were identified as being good tracers to distinguish the paddy stubble fire emissions in flaming $(0.38 \pm 0.11)$ and smouldering stages $(1.40 \pm 0.10)$, garbage burning emissions $(0.26-0.59)$ and traffic emissions $(3.54 \pm 0.21)$.

vi. The $i$-butane / $n$-butane ratio was found to be similar $(0.20-0.30)$ for many sources, and therefore, caution must be taken while using it in complex emission environments. Instead, the $i$-pentane $/ n$-pentane ratio turned out to be a better tracer for distinguishing biomass burning emissions (0.06-1.46) from petroldominated traffic and fossil fuel emissions (2.83-4.13).

These source profiles can be used for accurate and reliable emission calculations, source apportionment studies and to assess the choice of fuels from the point of view of air quality impacts, both as primary emission sources and also their potential to form secondary air pollutants like ozone and particulate matter. Ambient traffic emissions were found to be dominated by the petrol exhaust emissions due to the typically higher fraction of petrol-fuelled vehicles among the on-road intracity vehicular fleet in India. The potential toxicity and health impacts of the emission sources were assessed by using the BTEX fraction as a metric, and petrol exhaust, paddy stubble fires and garbage fires were ranked higher in toxicity than other emissions, based on this metric. Based on our limited measurements of ambient benzene in the traffic thoroughfares, the mass concentration was $6.1 \pm 1.3 \mu \mathrm{g} \mathrm{m}^{-3}$, which is higher than the $5 \mu \mathrm{g} \mathrm{m}^{-3}$ annual exposure limit set in the National Ambient Air Quality Standards (NAAQS) of India (NAAQS, 2009). Future studies should quantify the annual ambient exposure of such toxic compounds from the sources which have a high BTEX content to assess compliance with the annual ambient air quality standards as has previously been done for paddy residue smoke (Chandra and Sinha, 2016). The diesel and petrol vehicular exhaust emissions, paddy stubble fire and garbage fire emissions were identified as being the most polluting emission sources in terms of $\mathrm{OH}$ reactivity and ozone formation potentials. Although LPG and CNG vehicular exhaust emissions were cleaner, they were comprised of large fractions of alkenes due to the improper combustion of fuels. Thus, they 
can impact local air quality and atmospheric chemistry, and therefore, the use of improved VOC scrubbing technologies, cleaner fuels and reduced idling times of the vehicles should be promoted.

The results and insights obtained from this study will aid in the identification of factor profiles in source apportionment models, such as positive matrix factorisation, yielding more accurate quantitative data for the mitigation of ambient air pollution.

Data availability. Data are available from the corresponding author upon request.

Supplement. The supplement related to this article is available online at: https://doi.org/10.5194/acp-20-12133-2020-supplement.

Author contributions. VS and AK conceived and designed the study. AK carried out the sample collection, field work and performed TD-GC-FID measurements with the help of MS and $\mathrm{HH}$ and the advice of BB concerning the analytical system. AK carried out the preliminary analysis and wrote the first draft. VS revised the paper and carried out the advanced analyses and interpretation of the data and supervised all experimental aspects of the work. VG participated in the discussion of the analytical system and commented on the paper.

Competing interests. The authors declare that they have no conflict of interest.

Acknowledgements. We acknowledge the IISER Mohali Atmospheric Chemistry Facility for the data and the Ministry of Human Resource Development (MHRD), India, for funding the facility. Ashish Kumar, Haseeb Hakkim and Muhammed Shabin acknowledge MHRD and IISER Mohali for the doctoral (SRF and JRF) fellowships. We acknowledge EGU for the waiver of the APC through the EGU 2019 OSPP award to Ashish Kumar. We also thank Baerbel Sinha (Department of Earth and Environmental Sciences, Indian Institute of Science Education and Research, Mohali) and the two anonymous reviewers for their helpful suggestions and insightful comments which helped to improve the paper. We also acknowledge the help and support of the members of IISER Mohali Atmospheric Chemistry facility, namely Harshita Pawar, Pallavi, Abhishek Mishra, Abhishek Verma, Bharti Sohpaul and Tess George for their technical assistance during field sampling.

Financial support. This research has been supported by the National Mission on Strategic knowledge for Climate Change (NMSKCC) MRDP Program of the Department of Science and Technology, India vide grant (SPLICE; grant no: DST/CCP/MRDP/100/2017(G)).
Review statement. This paper was edited by Eliza Harris and reviewed by two anonymous referees.

\section{References}

ACTRiS: WP4-NA4: The ACTRIS measurement guidelines for submission of VOC data, available at: https://actris.nilu.no/ Content $/$ ?pageid=68159644c2c04d648ce41536297f5b93 (last access: 19 December 2019), 2014.

Akagi, S. K., Yokelson, R. J., Wiedinmyer, C., Alvarado, M. J., Reid, J. S., Karl, T., Crounse, J. D., and Wennberg, P. O.: Emission factors for open and domestic biomass burning for use in atmospheric models, Atmos. Chem. Phys., 11, 4039-4072, https://doi.org/10.5194/acp-11-4039-2011, 2011.

Andreae, M. O.: Emission of trace gases and aerosols from biomass burning - an updated assessment, Atmos. Chem. Phys., 19, 8523-8546, https://doi.org/10.5194/acp-19-8523-2019, 2019.

Anyon, P., Pattison, B.-A., and Trompp, W.: Toxic emissions from diesel vehicles in Australia, Technical Report No. 1, Parsons Australia Pty Ltd, Environment Australia, 2003, available at: https://p2infohouse.org/ref/37/36467.pdf, last access: 4 September 2020 .

Apel, E., Emmons, L., Karl, T., Flocke, F., Hills, A., Madronich, S., Lee-Taylor, J., Fried, A., Weibring, P., and Walega, J.: Chemical evolution of volatile organic compounds in the outflow of the Mexico City Metropolitan area, Atmos. Chem. Phys., 10, 23532375, https://doi.org/10.5194/acp-10-2353-2010, 2010.

Atkinson, R.: Gas-phase tropospheric chemistry of volatile organic compounds: 1. Alkanes and alkenes, J. Phys. Chem. Ref. Data, 26, 215-290, 1997.

Atkinson, R.: Atmospheric chemistry of VOCs and $\mathrm{NO}_{x}$, Atmos. Environ., 34, 2063-2101, https://doi.org/10.1016/S13522310(99)00460-4, 2000.

Atkinson, R., Aschmann, S. M., Winer, A. M., and Pitts Jr, J. N.: Rate Constants for the Reaction of $\mathrm{OH}$ Radicals with a Series of Alkanes and Alkenes at 299 \pm 2 K, Int. J. Chem. Kinet., 14, 507-516, https://doi.org/10.1002/kin.550140508, 1982.

Atkinson, R., Baulch, D., and Cox, R.: J. Phys. Chem. Ref. Data, Monograph, 1, 1-246, 1989.

Atkinson, R., Baulch, D., Cox, R., Crowley, J., Hampson, R., Hynes, R., Jenkin, M., Rossi, M., Troe, J., and Subcommittee, I.: Evaluated kinetic and photochemical data for atmospheric chemistry: Volume II - gas phase reactions of organic species, Atmos. Chem. Phys., 6, 3625-4055, https://doi.org/10.5194/acp-6-36252006, 2006.

ATSDR (The Agency for Toxic Substances and Disease Registry): U.S. Department of Health and Human Services. Toxicological Profile For Toluene, available at: http://www.atsdr.cdc. gov/toxprofiles/tp.asp?id=161\&tid=29 (last access: 4 September 2020), 2000.

ATSDR (The Agency for Toxic Substances and Disease Registry): U.S. Department of Health and Human Services. Toxicological Profile For Xylene, available at: http://www.atsdr.cdc. gov/toxprofiles/tp.asp?id=296\&tid=53 (last access: 4 September 2020), 2007.

Badarinath, K., Chand, T., and Prasad, V. K.: Agriculture crop residue burning in the Indo-Gangetic Plains - A study using IRSP6 AWiFS satellite data, Current Sci., 91, 1085-1089, 2006. 
Badol, C., Borbon, A., Locoge, N., Léonardis, T., and Galloo, J.-C.: An automated monitoring system for VOC ozone precursors in ambient air: development, implementation and data analysis, Anal. Bioanal. Chem., 378, 1815-1827, https://doi.org/10.1007/s00216-003-2474-0, 2004.

Baker, A. K., Beyersdorf, A. J., Doezema, L. A., Katzenstein, A., Meinardi, S., Simpson, I. J., Blake, D. R., and Sherwood Rowland, F.: Measurements of nonmethane hydrocarbons in 28 United States cities, Atmos. Environ.t, 42, 170-182, https://doi.org/10.1016/j.atmosenv.2007.09.007, 2008.

Barletta, B., Meinardi, S., Simpson, I. J., Khwaja, H. A., Blake, D. R., and Rowland, F. S.: Mixing ratios of volatile organic compounds (VOCs) in the atmosphere of Karachi, Pakistan, Atmos. Environ., 36, 3429-3443, https://doi.org/10.1016/S13522310(02)00302-3, 2002.

Barletta, B., Meinardi, S., Rowland, F. S., Chan, C.-Y., Wang, X., Zou, S., Chan, L. Y., and Blake, D. R.: Volatile organic compounds in 43 Chinese cities, Atmos. Environ., 39, 5979-5990, https://doi.org/10.1016/j.atmosenv.2005.06.029, 2005.

Barletta, B., Simpson, I. J., Blake, N. J., Meinardi, S., Emmons, L. K., Aburizaiza, O. S., Siddique, A., Zeb, J., Liya, E. Y., and Khwaja, H. A.: Characterization of carbon monoxide, methane and nonmethane hydrocarbons in emerging cities of Saudi Arabia and Pakistan and in Singapore, J. Atmos. Chem., 74, 87-113, https://doi.org/10.1007/s10874-016-9343-7, 2017.

Blake, D. R. and Rowland, F. S.: Urban leakage of liquefied petroleum gas and its impact on Mexico City air quality, Science, 269, 953-956, https://doi.org/10.1126/science.269.5226.953, 1995.

Borbon, A., Fontaine, H., Veillerot, M., Locoge, N., Galloo, J., and Guillermo, R.: An investigation into the traffic-related fraction of isoprene at an urban location, Atmos. Environ., 35, 3749-3760, https://doi.org/10.1016/S1352-2310(01)00170-4, 2001.

Brodrick, C.-J., Dwyer, H. A., Farshchi, M., Harris, D. B., and King Jr, F. G.: Effects of engine speed and accessory load on idling emissions from heavy-duty diesel truck engines, J. Air Waste Manage., 52, 1026-1031, https://doi.org/10.1080/10473289.2002.10470838, 2002.

Buczynska, A. J., Krata, A., Stranger, M., Godoi, A. F. L., Kontozova-Deutsch, V., Bencs, L., and Van Grieken, R.: Atmospheric BTEX-concentrations in an area with intensive street traffic, Atmos. Environ., 43, 311-318, https://doi.org/10.1016/j.atmosenv.2008.09.071, 2009.

Carter, W. P.: Updated maximum incremental reactivity scale and hydrocarbon bin reactivities for regulatory applications, California Air Resources Board Contract, 07-339, available at: https: //www.arb.ca.gov/regact/2009/mir2009/mir10.pdf (last access: 4 September 2020), 2009.

Carter, W. P. L.: Development of Ozone Reactivity Scales for Volatile Organic Compounds, Air Waste, 44, 881-899, https://doi.org/10.1080/1073161X.1994.10467290, 1994.

Chandra, B. P. and Sinha, V.: Contribution of post-harvest agricultural paddy residue fires in the NW Indo-Gangetic Plain to ambient carcinogenic benzenoids, toxic isocyanic acid and carbon monoxide, Environ. Int., 88, 187-197, https://doi.org/10.1016/j.envint.2015.12.025, 2016.

Chandra, B., Sinha, V., Hakkim, H., and Sinha, B.: Storage stability studies and field application of low cost glass flasks for analyses of thirteen ambient VOCs using proton trans- fer reaction mass spectrometry, Int. J. Mass Sp., 419, 11-19, https://doi.org/10.1016/j.ijms.2017.05.008, 2017.

Chang, C.-C., Lo, J.-G., and Wang, J.-L.: Assessment of reducing ozone forming potential for vehicles using liquefied petroleum gas as an alternative fuel, Atmos. Environ., 35, 6201-6211, https://doi.org/10.1016/S1352-2310(01)00386-7, 2001.

Chen, K., Lai, C., and Ho, Y.: Source profiles and ozone formation potentials of volatile organic compounds in three traffic tunnels in Kaohsiung, Taiwan, J. Air Waste Manage., 53, 102-112, https://doi.org/10.1080/10473289.2003.10466114, 2003.

Costagliola, M. A., Murena, F., and Prati, M. V.: Exhaust emissions of volatile organic compounds of powered two-wheelers: Effect of cold start and vehicle speed. Contribution to greenhouse effect and tropospheric ozone formation, Sci. Total Environ., 468, 1043-1049, https://doi.org/10.1016/j.scitotenv.2013.09.025, 2014.

Dallmann, T. R., DeMartini, S. J., Kirchstetter, T. W., Herndon, S. C., Onasch, T. B., Wood, E. C., and Harley, R. A.: On-road measurement of gas and particle phase pollutant emission factors for individual heavy-duty diesel trucks, Environ. Sci. Technol., 46, 8511-8518, https://doi.org/10.1021/es301936c, 2012.

Deng, C., Jin, Y., Zhang, M., Liu, X., and Yu, Z.: Emission characteristics of VOCs from on-road vehicles in an urban tunnel in eastern China and predictions for 2017-2026, Aerosol Air Qual. Res., 18, 3025-3034, https://doi.org/10.4209/aaqr.2018.07.0248, 2018.

Derwent, R. G., Jenkin, M. E., Utembe, S. R., Shallcross, D. E., Murrells, T. P., and Passant, N. R.: Secondary organic aerosol formation from a large number of reactive manmade organic compounds, Sci. Total Environ., 408, 3374-3381, https://doi.org/10.1016/j.scitotenv.2010.04.013, 2010.

Doskey, P. V., Fukui, Y., Sultan, M., Al Maghraby, A., and Taher, A.: Source profiles for nonmethane organic compounds in the atmosphere of Cairo, Egypt, J. Air Waste Manage., 49, 814-822, https://doi.org/10.1080/10473289.1999.10463850, 1999.

Dröge, R., Hensema, A., ten Broeke, H., and Hulskotte, J.: Emissions of two-wheeled vehicles, Utrecht: TNO, TNO-060-UT2011-01556, 2011.

Garg, S., Chandra, B. P., Sinha, V., Sarda-Esteve, R., Gros, V., and Sinha, B.: Limitation of the Use of the Absorption Angstrom Exponent for Source Apportionment of Equivalent Black Carbon: a Case Study from the North West Indo-Gangetic Plain, Environ. Sci. Technol., 50, 814-824, https://doi.org/10.1021/acs.est.5b03868, 2016.

Gentner, D. R., Isaacman, G., Worton, D. R., Chan, A. W., Dallmann, T. R., Davis, L., Liu, S., Day, D. A., Russell, L. M., and Wilson, K. R.: Elucidating secondary organic aerosol from diesel and gasoline vehicles through detailed characterization of organic carbon emissions, P. Natl. Acad. Sci. USA, 109, 1831818323, https://doi.org/10.1073/pnas.1212272109, 2012.

GoI: Gazette of India BS VI notification 2016, available at: http: //egazette.nic.in/WriteReadData/2016/168300.pdf, last access: 4 September 2020, 2016.

Goel, R. and Guttikunda, S. K.: Evolution of on-road vehicle exhaust emissions in Delhi, Atmos. Environ., 105, 78-90, https://doi.org/10.1016/j.atmosenv.2015.01.045, 2015.

Goyal, P. and Sidhartha: Present scenario of air quality in Delhi: a case study of CNG implementation, Atmos. Environ., 37, 54235431, https://doi.org/10.1016/j.atmosenv.2003.09.005, 2003. 
Gros, V., Gaimoz, C., Herrmann, F., Custer, T., Williams, J., Bonsang, B., Sauvage, S., Locoge, N., d'Argouges, O., and SardaEstève, R.: Volatile organic compounds sources in Paris in spring 2007, Part I: qualitative analysis, Environ. Chem., 8, 74-90, https://doi.org/10.1071/EN10068, 2011.

Guo, H., Zou, S. C., Tsai, W. Y., Chan, L. Y., and Blake, D. R.: Emission characteristics of nonmethane hydrocarbons from private cars and taxis at different driving speeds in Hong Kong, Atmos. Environ.t, 45, 2711-2721, https://doi.org/10.1016/j.atmosenv.2011.02.053, 2011.

Guttikunda, S. K. and Mohan, D.: Re-fueling road transport for better air quality in India, Energ. Policy, 68, 556-561, https://doi.org/10.1016/j.enpol.2013.12.067, 2014.

Hallquist, M., Wenger, J. C., Baltensperger, U., Rudich, Y., Simpson, D., Claeys, M., Dommen, J., Donahue, N. M., George, C., Goldstein, A. H., Hamilton, J. F., Herrmann, H., Hoffmann, T., Iinuma, Y., Jang, M., Jenkin, M. E., Jimenez, J. L., KiendlerScharr, A., Maenhaut, W., McFiggans, G., Mentel, T. F., Monod, A., Prévôt, A. S. H., Seinfeld, J. H., Surratt, J. D., Szmigielski, R., and Wildt, J.: The formation, properties and impact of secondary organic aerosol: current and emerging issues, Atmos. Chem. Phys., 9, 5155-5236, https://doi.org/10.5194/acp-9-51552009, 2009.

Harley, R. A., Coulter-Burke, S. C., and Yeung, T. S.: Relating Liquid Fuel and Headspace Vapor Composition for California Reformulated Gasoline Samples Containing Ethanol, Environ. Sci. Technol., 34, 4088-4094, https://doi.org/10.1021/es0009875, 2000.

Ho, K. F., Lee, S. C., Ho, W. K., Blake, D. R., Cheng, Y., Li, Y. S., Ho, S. S. H., Fung, K., Louie, P. K. K., and Park, D.: Vehicular emission of volatile organic compounds (VOCs) from a tunnel study in Hong Kong, Atmos. Chem. Phys., 9, 7491-7504, https://doi.org/10.5194/acp-9-7491-2009, 2009.

Hong-li, W., Sheng-ao, J., Sheng-rong, L., Qing-yao, H., Li, L., Shikang, T., Cheng, H., Li-ping, Q., and Chang-hong, C.: Volatile organic compounds (VOCs) source profiles of on-road vehicle emissions in China, Sci. Total Environ., 607/608, 253-261, https://doi.org/10.1016/j.scitotenv.2017.07.001, 2017.

Hoque, R. R., Khillare, P. S., Agarwal, T., Shridhar, V., and Balachandran, S.: Spatial and temporal variation of BTEX in the urban atmosphere of Delhi, India, Sci. Total Environ., 392, 30-40, https://doi.org/10.1016/j.scitotenv.2007.08.036, 2008.

Huang, Y., Ling, Z. H., Lee, S. C., Hang Ho, S. S., Cao, J. J., Blake, D., Cheng, Y., Lai, S. C., Ho, K. F.,Gao, Y., and Louie, P. K. $\mathrm{K}$ : Characterization of volatile organic compounds at a roadside environment in Hong Kong: an investigation of influences after air pollution control strategies. Atmos. Environ., 122, 809-818, https://doi.org/10.1016/j.atmosenv.2015.09.036, 2015.

Hwa, M.-Y., Hsieh, C.-C., Wu, T.-C., and Chang, L.-F. W.: Realworld vehicle emissions and VOCs profile in the Taipei tunnel located at Taiwan Taipei area, Atmos. Environ.t, 36, 1993-2002, https://doi.org/10.1016/S1001-0742(10)60500-1, 2002.

IARC: Chemical Agents and Related Occupations, Monographs on the Evaluation of Carcinogenic Risks to Humans, 100, 249-285, 309-333, available at: https://monographs.iarc.fr/wp-content/ uploads/2018/06/mono100F.pdf (last access: 4 September 2020), 2012.

Jobson, B. T., McKeen, S. A., Parrish, D. D., Fehsenfeld, F. C., Blake, D. R., Goldstein, A. H., Schauffler,
S. M., and Elkins, J. W.: Trace gas mixing ratio variability versus lifetime in the troposphere and stratosphere: Observations, J. Geophys. Res.-Atmos., 104, 16091-16113, https://doi.org/10.1029/1999jd900126, 1999.

Jaimes-Palomera, M., Retama, A., Elias-Castro, G., NeriaHernández, A., Rivera-Hernández, O., and Velasco, E.: Nonmethane hydrocarbons in the atmosphere of Mexico City: Results of the 2012 ozone-season campaign, Atmos. Environ., 132, 258-275, https://doi.org/10.1016/j.atmosenv.2016.02.047, 2016.

Kansal, A.: Sources and reactivity of NMHCs and VOCs in the atmosphere: A review, J. Hazard. Mater., 166, 17-26, https://doi.org/10.1016/j.jhazmat.2008.11.048, 2009.

Kumar, V., Sarkar, C., and Sinha, V.: Influence of post-harvest crop residue fires on surface ozone mixing ratios in the NW IGP analyzed using 2 years of continuous in situ trace gas measurements, J. Geophys. Res.-Atmos., 121, 3619-3633, https://doi.org/10.1002/2015JD024308, 2016.

Kumar, V., Chandra, B., and Sinha, V.: Large unexplained suite of chemically reactive compounds present in ambient air due to biomass fires, Sci. Rep., 8, 626, https://doi.org/10.1038/s41598017-19139-3, 2018.

Lai, C.-H., Chang, C.-C., Wang, C.-H., Shao, M., Zhang, Y., and Wang, J.-L.: Emissions of liquefied petroleum gas (LPG) from motor vehicles, Atmos. Environ., 43, 1456-1463, https://doi.org/10.1016/j.atmosenv.2008.11.045, 2009.

Lemieux, P. M., Lutes, C. C., and Santoianni, D. A.: Emissions of organic air toxics from open burning: a comprehensive review, Prog. Energ. Combust. Sci., 30, 1-32, https://doi.org/10.1016/j.pecs.2003.08.001, 2004.

Liu, Y., Shao, M., Fu, L., Lu, S., Zeng, L., and Tang, D.: Source profiles of volatile organic compounds (VOCs) measured in China: Part I, Atmos. Environ., 42, 6247-6260, https://doi.org/10.1016/j.atmosenv.2008.01.070, 2008.

McKeen, S. and Liu, S.: Hydrocarbon ratios and photochemical history of air masses, Geophys. Res. Lett., 20, 2363-2366, https://doi.org/10.1029/93GL02527, 1993.

Mo, Z., Shao, M., and Lu, S.: Compilation of a source profile database for hydrocarbon and OVOC emissions in China, Atmos. Environ., 143, 209-217, https://doi.org/10.1016/j.atmosenv.2016.08.025, 2016.

MoRTH: MOTOR VEHICLES - Statistical Year Book India; Directorate of Economics and Statistics, Ministry of Road Transport and Highways, Government of India, available at: http: //mospi.nic.in/statistical-year-book-india/2017/189 (last access: 4 September 2020), 2017.

MoRTH: MOTOR VEHICLES - Statistical Year Book India; Directorate of Economics and Statistics, Ministry of Road Transport and Highways, Government of India, available at: http: //mospi.nic.in/statistical-year-book-india/2018/189 (last access: 4 September 2020), 2018.

Mugica, V., Vega, E., Arriaga, J. L., and Ruiz, M. E.: Determination of motor vehicle profiles for non-methane organic compounds in the Mexico City metropolitan area, J. Air Waste Manage., 48, 1060-1068, 1998.

Na, K., Kim, Y. P., Moon, I., and Moon, K.-C.: Chemical composition of major VOC emission sources in the Seoul atmosphere, Chemosphere, 55, 585-594, https://doi.org/10.1016/j.chemosphere.2004.01.010, 2004. 
NAAQS (National Ambient Air Quality Standards): Central Pollution Control Board, New Delhi, available at: https://scclmines. com/env/DOCS/NAAQS-2009.pdf (last access: 22 October 2020), 2009.

Niedojadlo, A., Becker, K. H., Kurtenbach, R., and Wiesen, P.: The contribution of traffic and solvent use to the total NMVOC emission in a German city derived from measurements and CMB modelling, Atmos. Environ., 41, 7108-7126, https://doi.org/10.1016/j.atmosenv.2007.04.056, 2007.

Nielsen: All India study on sectoral demand of diesel \& petrol: Report - Petroleum planning and analysis cell, available at: http://ppac.org.in/WriteReadData/Reports/ 201411110329450069740AllIndiaStudyonSectoralDemandofDiese pdf (last access: 4 September 2020), 2013.

Ortega, A. M., Hayes, P. L., Peng, Z., Palm, B. B., Hu, W., Day, D. A., Li, R., Cubison, M. J., Brune, W. H., Graus, M., Warneke, C., Gilman, J. B., Kuster, W. C., de Gouw, J., GutiérrezMontes, C., and Jimenez, J. L.: Real-time measurements of secondary organic aerosol formation and aging from ambient air in an oxidation flow reactor in the Los Angeles area, Atmos. Chem. Phys., 16, 7411-7433, https://doi.org/10.5194/acp16-7411-2016, 2016.

Parrish, D. D., Hahn, C. J., Williams, E. J., Norton, R. B., Fehsenfeld, F. C., Singh, H. B., Shetter, J. D., Gandrud, B. W., and Ridley, B. A.: Indications of photochemical histories of Pacific air masses from measurements of atmospheric trace species at Point Arena, California, J. Geophys. Res.-Atmos., 97, 15883-15901, https://doi.org/10.1029/92jd01242, 1992.

Parrish, D. D., Trainer, M., Young, V., Goldan, P. D., Kuster, W. C., Jobson, B. T., Fehsenfeld, F. C., Lonneman, W. A., Zika, R. D., Farmer, C. T., Riemer, D. D., and Rodgers, M. O.: Internal consistency tests for evaluation of measurements of anthropogenic hydrocarbons in the troposphere, J. Geophys. Res.-Atmos., 103, 22339-22359, https://doi.org/10.1029/98jd01364, 1998.

Passant, N.: Speciation of UK emissions of non-methane volatile organic compounds, AEA Technology, available at: https://uk-ir.defra.gov.uk/assets/documents/reports/empire/ AEAT_ENV_0545_final_v2.pdf (last access: 4 September 2020), 2002.

Penkett, S.: GAW Report No. 171: A WMO/GAW Expert Workshop on Global Long-Term Measurements of Volatile Organic Compounds (VOCs), WMO Geneva, TD, 2007.

Poisson, N., Kanakidou, M., and Crutzen, P. J.: Impact of Non-Methane Hydrocarbons on Tropospheric Chemistry and the Oxidizing Power of the Global Troposphere: 3Dimensional Modelling Results, J. Atmos. Chem., 36, 157-230, https://doi.org/10.1023/a:1006300616544, 2000.

Prakash, J. and Habib, G.: A technology-based mass emission factors of gases and aerosol precursor and spatial distribution of emissions from on-road transport sector in India, Atmos. Environ., 180, 192-205, https://doi.org/10.1016/j.atmosenv.2018.02.053, 2018.

Rahman, S. A., Masjuki, H., Kalam, M., Abedin, M., Sanjid, A., and Sajjad, H.: Impact of idling on fuel consumption and exhaust emissions and available idle-reduction technologies for diesel vehicles - A review, Energ. Conv. Manage., 74, 171-182, https://doi.org/10.1016/j.enconman.2013.05.019, 2013.

Reiter, M. S. and Kockelman, K. M.: The problem of cold starts: A closer look at mobile source emissions levels, Transport. Res.
D-Tr. E., 43, 123-132, https://doi.org/10.1016/j.trd.2015.12.012, 2016.

Sadavarte, P. and Venkataraman, C.: Trends in multi-pollutant emissions from a technology-linked inventory for India: I. Industry and transport sectors, Atmos. Environ., 99, 353-364, https://doi.org/10.1016/j.atmosenv.2014.09.081, 2014.

Sahai, S., Sharma, C., Singh, D., Dixit, C., Singh, N., Sharma, P., Singh, K., Bhatt, S., Ghude, S., and Gupta, V.: A study for development of emission factors for trace gases and carbonaceous particulate species from in situ burning of wheat straw in agricultural fields in India, Atmos. Environ., 41, 9173-9186, https://doi.org/10.1016/j.atmosenv.2007.07.054, 2007.

. Sahu, S. K., Beig, G., and Parkhi, N.: Critical emissions from the largest on-road transport network in South Asia, Aerosol Air Qual.Res., 14, 135-144, https://doi.org/10.4209/aaqr.2013.04.01372014.

Sarkar, C., Kumar, V., and Sinha, V.: Massive emissions of carcinogenic benzenoids from paddy residue burning in North India, Curr. Sci. India, 104, 1703-1706, 2013.

Schauer, J. J., Kleeman, M. J., Cass, G. R., and Simoneit, B. R.: Measurement of emissions from air pollution sources, 2. $\mathrm{C}_{1}$ through $\mathrm{C}_{30}$ organic compounds from medium duty diesel trucks, Environ. Sci. Technol., 33, 1578-1587, https://doi.org/10.1021/es980081n, 1999.

Shancita, I., Masjuki, H., Kalam, M., Fattah, I. R., Rashed, M., and Rashedul, H.: A review on idling reduction strategies to improve fuel economy and reduce exhaust emissions of transport vehicles, Energ. Conv.Manage., 88, 794-807, https://doi.org/10.1016/j.enconman.2014.09.036, 2014.

Sharma, G., Sinha, B., Pallavi, Hakkim, H., Chandra, B. P., Kumar, A., and Sinha, V.: Gridded Emissions of $\mathrm{CO}, \mathrm{NOx}, \mathrm{SO}_{2}, \mathrm{CO}_{2}$, $\mathrm{NH}_{3}, \mathrm{HCl}, \mathrm{CH}_{4}, \mathrm{PM}_{2.5}, \mathrm{PM}_{10}, \mathrm{BC}$, and NMVOC from Open Municipal Waste Burning in India, Environ. Sci. Technol., 53, 4765-4774, https://doi.org/10.1021/acs.est.8b07076, 2019.

Siegl, W. O., Hammerle, R. H., Herrmann, H. M., Wenclawiak, B. W., and Luers-Jongen, B.: Organic emissions profile for a light-duty diesel vehicle, Atmos. Environ., 33, 797-805, https://doi.org/10.1016/S1352-2310(98)00209-X, 1999.

Sinha, V., Williams, J., Diesch, J., Drewnick, F., Martinez, M., Harder, H., Regelin, E., Kubistin, D., Bozem, H., and HosaynaliBeygi, Z.: Constraints on instantaneous ozone production rates and regimes during DOMINO derived using in-situ $\mathrm{OH}$ reactivity measurements, Atmos. Chem. Phys., 12, 7269-7283, https://doi.org/10.5194/acp-12-7269-2012, 2012.

Sinha, V., Hakkim, H., and Kumar, V.: Advances in Identification and Quantification of Non-methane Volatile Organic Compounds Emitted from Biomass Fires through Laboratory Fire Experiments, in: Advances in Atmospheric Chemistry, Volume 2: Organic oxidation and multiphase chemistry, edited by: Barker, J. R., Steiner, A. L., and Wallington, T. J., World Scientific, Singapore, 169-197, https://doi.org/10.1142/9789813271838_0003, 2019.

Słomińska, M., Konieczka, P., and Namieśnik, J., The fate of BTEX compounds in ambient air, Crit. Rev. Env. Sci. Tec., 44, 455-472, https://doi.org/10.1080/10643389.2012.728808, 2014.

Tang, W., Hemm, I., and Eisenbrand, G.: Estimation of human exposure to styrene and ethylbenzene, Toxicology, 144, 39-50, https://doi.org/10.1016/S0300-483X(99)00188-2, 2000. 
Tsai, J.-H., Chang, S.-Y., and Chiang, H.-L.: Volatile organic compounds from the exhaust of lightduty diesel vehicles, Atmos. Environ., 61, 499-506, https://doi.org/10.1016/j.atmosenv.2012.07.078, 2012.

Tsai, J.-H., Huang, P.-H., and Chiang, H.-L.: Characteristics of volatile organic compounds from motorcycle exhaust emission during real-world driving, Atmos. Environ., 99, 215-226, https://doi.org/10.1016/j.atmosenv.2014.09.076, 2014.

Tsai, W. Y., Chan, L. Y., Blake, D. R., and Chu, K. W.: Vehicular fuel composition and atmospheric emissions in South China: Hong Kong, Macau, Guangzhou, and Zhuhai, Atmos. Chem. Phys., 6, 3281-3288, https://doi.org/10.5194/acp-6-3281-2006, 2006.

EPA: Clean Air Act Amendments 1990, United States Environmental Protection Agency, Office of Air and Radiation, Pennsylvania Ave., Washington, D.C., available at: https://www.epa.gov/clean-air-act-overview/ 1990-clean-air-act-amendment-summary-title-i (last access: 4 September 2020), 1990.

Venkataraman, C., Habib, G., Kadamba, D., Shrivastava, M., Leon, J. F., Crouzille, B., Boucher, O., and Streets, D.: Emissions from open biomass burning in India: Integrating the inventory approach with high-resolution Moderate Resolution Imaging Spectroradiometer (MODIS) active-fire and land cover data, Global Biogeochem. Cy., 20, https://doi.org/10.1029/2005GB002547, 2006.

Vettikkat, L., Sinha, V., Datta, S., Kumar, A., Hakkim, H., Yadav, P., and Sinha, B.: Significant emissions of dimethyl sulfide and monoterpenes by big-leaf mahogany trees: discovery of a missing dimethyl sulfide source to the atmospheric environment, Atmos. Chem. Phys., 20, 375-389, https://doi.org/10.5194/acp-20375-2020, 2020.

Wang, P. and Zhao, W.: Assessment of ambient volatile organic compounds (VOCs) near major roads in urban Nanjing, China, Atmos. Res., 89, 289-297, https://doi.org/10.1016/j.atmosres.2008.03.013, 2008.
Watson, J. G., Chow, J. C., and Fujita, E. M.: Review of volatile organic compound source apportionment by chemical mass balance, Atmos. Environ., 35, 1567-1584, https://doi.org/10.1016/S1352-2310(00)00461-1, 2001.

Yamada, H., Misawa, K., Suzuki, D., Tanaka, K., Matsumoto, J., Fujii, M., and Tanaka, K.: Detailed analysis of diesel vehicle exhaust emissions: Nitrogen oxides, hydrocarbons and particulate size distributions, P. Combust. Inst., 33, 2895-2902, https://doi.org/10.1016/j.proci.2010.07.001, 2011.

Yamamoto, Y., Kambe, Y., Yamada, H., and Tonokura, K.: Measurement of volatile organic compounds in vehicle exhaust using single-photon ionisation time-of-flight mass spectrometry, Anal. Sci., 28, 385-385, https://doi.org/10.2116/analsci.28.385, 2012.

Zhang, Y., Wang, X., Zhang, Z., Lü, S., Shao, M., Lee, F. S., and Yu, J.: Species profiles and normalised reactivity of volatile organic compounds from gasoline evaporation in China, Atmos. Environ., 79, 110-118, https://doi.org/10.1016/j.atmosenv.2013.06.029, 2013.

Zhang, Q., Wu, L., Fang, X., Liu, M., Zhang, J., Shao, M., Lu, S., and Mao, H.: Emission factors of volatile organic compounds (VOCs) based on the detailed vehicle classification in a tunnel study, Sci. Total Environ., 624, 878-886, https://doi.org/10.1016/j.scitotenv.2017.12.171, 2018.

Zheng, J., Yu, Y., Mo, Z., Zhang, Z., Wang, X., Yin, S., Peng, K., Yang, Y., Feng, X., and Cai, H.: Industrial sector-based volatile organic compound (VOC) source profiles measured in manufacturing facilities in the Pearl River Delta, China, Sci. Total Environ.t, 456, 127-136, https://doi.org/10.1016/j.scitotenv.2013.03.055, 2013. 